\title{
Den of Inequity: The Case for Equitable Doctrines in Rule 10b-5 Cases
}

\author{
Christopher R. Leslie $†$
}

In Lampf, Pleva, Lipkind, Prupis \& Petigrow v. Gilbertson, the Supreme Court established a three-year statute of repose on all private claims for securities fraud brought under Rule 10b-5 and section 10(b) of the Securities Exchange Act of 1934. A statute of repose prevents the operation of doctrines of equitable tolling and equitable estoppel. In this Comment, the author argues that such doctrines should be applied to Rule $10 b-5$ fraud; the statute of limitations for such fraud should not begin to run until the fraud has been discovered by the victim or would have been discovered had she exercised reasonable diligence. The Lampf Court failed to address underlying policy concerns. The purposes of securities regulation, including the deterrence of fraud and the compensation of victims by disgorging ill-gotten gains from wrongdoers, are better served by doctrines of equitable tolling and equitable estoppel. Even though statutes of repose may be appropriate for the express private causes of action in the Securities Exchange Act, they are unsuitable in the context of Rule 10b-5. The author concludes by proposing the necessary elements of a uniform federal doctrine of equitable tolling and equitable estoppel in Rule 10b-5 actions.

\section{INTRODUCTION}

In 1919, Charles Ponzi lent his name to the Ponzi scheme. The Ponzi scheme is a classic pyramid scam: "a fraudulent arrangement in which an entity makes payments to investors from monies obtained from later investors rather than from any 'profits' of the underlying business venture." A Ponzi scheme is a form of securities fraud which "consists of funnelling proceeds received from new investors to previous investors in the guise of profits from the alleged business venture, thereby cultivat-

Copyright (C) 1993 California Law Review, Inc.

$\dagger \quad$ Law Clerk, Judge Diarmud F. O'Scanlain, United States Court of Appeals for the Ninth Circuit. B.A. 1986, University of California; M.P.P. 1988, Harvard University, John F. Kennedy School of Government; J.D. 1993, Boalt Hall School of Law, University of California, Berkeley. I want to thank Professors Mel Eisenberg and Einer Elhauge for their suggestions and encouragement. All mistakes are mine alone.

1. In re United Energy Corp., 944 F.2d 589, 590 n.l (9th Cir. 1991). 
ing an illusion that a legitimate profit-making business opportunity exists and inducing further investment."2 But the Ponzi scheme had one inherent flaw: it needed a steady stream of new victims. Eventually, another layer of victims could not be added to the bottom of the pyramid, and the illegal structure would fall. Time was the enemy of Ponzi's scam. The pyramid could not stand forever; when it collapsed, the Ponzi entrepreneur could be held accountable to her victims.

In 1991, the Supreme Court solved the Ponzi artist's problem in Lampf, Pleva, Lipkind, Prupis \& Petigrow v. Gilbertson. ${ }^{3}$ The Court held that all private claims for securities fraud brought under Rule 10b-5 and section 10(b) of the Securities Exchange Act of 1934 (the "Exchange Act") must be brought within three years of the violation. ${ }^{4}$ Prior to Lampf, the statute of limitations for Rule 10b-5 violations did not begin to run until the victims of the securities fraud knew of the crime or should have known had they exercised due diligence. After Lampf, as long as the Ponzi operator can keep the pyramid standing for three years without selling additional fraudulent securities, she is not accountable to her victims. ${ }^{5}$ So while Charles Ponzi invented his illegal scheme in 1919, the Court perfected it in 1991.

By applying the doctrines of equitable tolling and equitable estoppel, this Comment argues for a retreat from the Lampf decision: the statute of limitations for Rule 10b-5 fraud should not begin to run until that fraud has been discovered by the victim or would have been discovered had he exercised reasonable diligence. This Comment is divided into four main parts. Part I introduces the basic concepts behind limitations periods and equitable doctrines. A statute of limitations defines the time in which a plaintiff must bring a suit. Equitable tolling allows courts to suspend the statute of limitations from running under certain conditions when a plaintiff does not know that he has been wronged. Equitable estoppel can be used to preclude a defendant from arguing a statute of limitations defense when the defendant has induced the plaintiff not to file suit in time. Finally, a statute of repose is a statute of limitations that is not subject to the equitable doctrines of tolling and estoppel.

Part II provides the legal background, explaining how and why the Supreme Court eliminated the application of equitable doctrines to securities fraud in order to establish a uniform statute of limitations for Rule 10b-5 cases. Part II serves two functions. First, it questions the Court's decision to graft onto Rule $10 \mathrm{~b}-5$ the statutes of limitations from the

2. Id. In addition to using many varieties of fraud to illustrate general principles, this Comment will specifically analyze Ponzi schemes, fraudulent municipal bonds, securities in underground natural resources, securities involving technical data, and limited partnership tax sheiters. See infra notes $189-226$ and accompanying text.

3. 111 S. Ct. 2773 (1991).

4. Id. at 2782 .

5. See infra notes 189-90 and accompanying text. 
Securities Act of 1933 (the "Securities Act"), all of which are statutes of repose. While this was a convenient statutory interpretation, the Court never addressed the complex and difficult question of whether eliminating equitable doctrines in Rule 10b-5 cases was good policy. Second, this Part emphasizes that a return to equitable tolling and equitable estoppel in Rule 10b-5 cases would not constitute dramatic change. Rather, it would constitute a return to what was, until Lampf, over forty years of well-established case law.

Part III presents the case for retaining equitable doctrines by independently discussing the purposes of both the securities laws and the statutes of limitations. Part III intends to show that eliminating equitable doctrines in Rule 10b-5 suits is both inappropriate and counter-productive. This Comment does not take a position on what the statute of limitations should be for Rule 10b-5 actions; rather, it argues that whatever the limitations period is, it should be subject to the equitable doctrines of tolling and estoppel. Also, Part III explains why statutes of repose may be appropriate for the express private causes of action and yet unsuitable for Rule 10b-5 cases.

Finally, Part IV proposes the necessary elements of a uniform federal doctrine of equitable tolling and equitable estoppel for Rule 10b-5 actions. It argues that the well-established case law favoring equitable doctrines provides guidance in determining the proper weight of the plaintiff's burden. Relying on the analysis developed in Part III, the Comment concludes that passive concealment may satisfy the fraudulent concealment requirement in some cases; due diligence should be required in all cases; and the standard for what constitutes due diligence should be lowered when the defendant actively conceals her crime and a fiduciary relationship exists between the defendant and the investor.

\section{I \\ BASIC CONCEPTS}

This Section serves as a basic overview of the concepts at play in this Comment. These concepts will be examined in greater depth throughout the course of the Comment, but a rudimentary explanation is necessary before discussing the current state of the law.

\section{A. Statutes of Limitations and Repose}

A statute of limitations defines the time period in which a plaintiff must bring suit against a defendant. As a rule, if the statute of limitations expires, a plaintiff may not bring a suit, regardless of its merits. In general, statutes of limitations are subject to equitable principles that determine when the limitations period starts to run and under what circumstances a defendant may be precluded from pleading a statute of lim- 
itations defense. $^{6}$

Statutes of limitations serve several functions. First, limitations periods "are primarily designed to assure fairness to defendants" and do so in two ways: they protect defendants against unfair surprise and allow them to make a "fresh start." The Court has explained that limitations periods "promote justice by preventing surprises through the revival of claims that have been allowed to slumber until evidence has been lost." In this way, preventing unfair surprise accommodates business planning and protects the reasonable expectations of potential defendants. Defendants may regularly expunge records, exculpatory or not, on the assumption that their potential liabilities expire with time. It would be unfair to punish defendants who destroyed exculpatory evidence based on a reasonable expectation of repose. The notion of the "fresh start" also serves fairness. As in bankruptcy, a "fresh start" acknowledges that even wrongdoers, at a certain point, have a right to get on with their lives with a clean slate, free from the fear of liability. Without using the language of "fresh start," the Court has reasoned "that even if one has a just claim it is unjust not to put the adversary on notice to defend within the period of limitation and that the right to be free of stale claims in time comes to prevail over the right to prosecute them." While the first fairness argument applies to both the honest and the culpable, the second one applies only to those defendants who have actually committed transgressions. ${ }^{10}$

Second, statutes of limitations preclude fraudulent or stale claims. This objective contains elements of both fact-finding and fairness. Without a limitations period, "the search for truth may be seriously impaired by the loss of evidence, whether by death or disappearance of witnesses, fading memories, disappearance of documents, or otherwise." ${ }^{11}$ This erosion of evidence is unfair to defendants because "[j]ust determinations of fact cannot be made when, because of the passage of time, the memories of witnesses have faded or evidence is lost," 12 and because incomplete facts increase the likelihood of fraudulent claims.

Third, statutes of limitations are imposed to facilitate business planning. Businesses need to assess liabilities in order to formulate long-term

6. The most important exception for our purposes is equitable estoppel, which occurs when a court precludes the defendant from arguing a statute of limitations defense because of the defendant's own actions. See infra notes 39-51 and accompanying text.

7. Burnett v. New York Cent. R.R., 380 U.S. 424, 428 (1965).

8. Order of R.R. Telegraphers v. Railway Express Agency, 321 U.S. 342, 348-49 (1944).

9. Id. at 349.

10. After all, the honest businesswoman does not need a fresh start, just as the financially solvent businessman does not need to declare bankruptcy.

11. United States v. Kubrick, 444 U.S. 111, 117 (1979).

12. Wilson v. Garcia, 471 U.S. 261, 271 (1985). 
strategies. These business purposes for limitations periods are discussed in the context of securities fraud in Part III.

Finally, the length of a statute of limitations must reflect a balance between deterring the initial crime and preventing fraudulent or stale claims. If the statute of limitations is too short, victims are less likely to bring suit in time, wrongdoers are less hikely to be held accountable, and deterrence of the initial crime is diminished. On the other hand, if there were no limitations period or it were too long, plaintiffs could bring suit after evidence had been destroyed and defendants were unable to properly defend themselves. The likelihood of fraudulent claims increases as time passes. Thus, the length of a statute of limitations represents a tradeoff between the risks of allowing false or stale claims and precluding honest ones. The Supreme Court has articulated this balance as "a value judgment concerning the point at which the interests in favor of protecting valid claims are outweighed by the interests in prohibiting the prosecution of stale ones."13

Statutes of limitations are sometimes called statutes of repose. ${ }^{14}$ However, there is a distinction. As used in this Comment, a statute of repose is a type of statute of limitations which is not subject to equitable principles. The Fourth Circuit explained that "a statute of repose is typically an absolute time limit beyond which liability no longer exists and is not tolled for any reason because to do so would upset the economic balance struck by the legislative body." "15 Thus, when applying statutes of repose, judges can not employ their equitable powers in tailoring the law to the specific circumstances.

Statutes of repose take many forms. The Double Jeopardy Clause has been called a statute of repose. ${ }^{16}$ Statutes of repose in other areas can serve purposes not relevant to the securities context. For example, in property law, statutes of repose serve to clarify land titles, eliminate massive litigation, and insure effective utilization of property. ${ }^{17}$

13. Johnson v. Railway Express Agency, 421 U.S. 454, 463-64 (1975).

14. See, e.g., Bridges v. United States, 346 U.S. 209, 231 (1953) (Reed, J., dissenting) ("[S]tatutes of limitation are statutes of repose.").

15. First United Methodist Church v. United States Gypsum Co., 882 F.2d 862, 866 (4th Cir. 1989), cert. denied, 493 U.S. 1070 (1990).

16. See Jones v. Thomas, 491 U.S. 376, 392 (1989) (Scalia, J., dissenting) (“[T]he Double Jeopardy Clause is a statute of repose for sentences as well as for proceedings.").

17. See, e.g., City of El Paso v. Simmons, 379 U.S. 497, 509-17 (1965) (describing factors that led Texas to enact a statute of repose limiting land reinstatement rights). Although the legality of statutes of repose has been questioned as an unconstitutional denial of access to the courts, their constitutionality has been repeatedly affirmed. See, e.g., Armbrister v. Roland Int'l Corp., 667 F. Supp. 802, 811-12 (M.D. Fla. 1987) (citing cases upholding the constitutionality af a statute of repose in product liability actions). 


\section{B. Equitable Concepts}

Law is built on tradition. This tradition is usually called precedent, but often may take the form of well-established principles which permeate all aspects of law. Equity is such a principle. The notion of equity, or fairness, provides judges with a safety valve so that they may do what is just or fair under the circumstances. Equitable doctrines were developed and expanded to protect litigants from any hidden unfairness not specifically addressed, or anticipated, by statute or precedent. Equitable doctrines are thus part of the balancing that courts must engage in to ensure that both parties to a dispute are treated fairly. Inflexible rules, such as statutes of repose, are inconsistent with equity, which requires individual tailoring to accommodate specific situations. The Supreme Court explained:

Equity eschews mechanical rules; it depends on flexibility. Equity has acted on the principle that "laches is not, like limitation, a mere matter of time; but principally a question of the inequity of permitting the claim to be enforced,-an inequity founded upon some change in the condition or relations of the property or the parties." 18

Equity is particularly important in securities regulation. For example, "[federal] courts possess broad equitable powers to order ancillary relief in order to effectuate the purposes of the securities laws." 19 Two of these equitable powers are equitable tolling and equitable estoppel. This Section introduces the equitable doctrines of tolling and estoppel, explaining how their flexible application facilitates fairness.

\section{Equitable Tolling}

In general, equitable tolling postpones a statute of limitations from running until the plaintiff is aware that she has a cause of action. In federal cases, the "[t]ime requirements in lawsuits between private litigants are customarily subject to 'equitable tolling." "20 In the context of securities fraud cases brought under Rule $10 \mathrm{~b}-5$, equitable tolling may be appropriate in two circumstances-when there is either fraudulent concealment or adverse domination. ${ }^{21}$

18. Holmberg v. Armbrecht, 327 U.S. 392, 396 (1946) (quoting Galliher v. Cadwell, 145 U.S. 368,373 (1892)). Laches is the common law doctrine whereby a defendant is granted an equitable defense because the plaintiff has allowed an undue lapse of time in enforcing a right of action and has been negligent in failing to act.

19. United States v. Cannistraro, 694 F. Supp. 62, 71 (D.N.J. 1988), aff'd in part and vacated in part, 871 F.2d 1210 (3d Cir. 1989).

20. Irwin v. Department of Veterans Affairs, 498 U.S. 89, 95 (1990) (quoting Hallstrom v. Tillamook County, 493 U.S. 20, 27 (1989)). In fact, the court describes this custom as a "rebuttable presumption." Id.

21. Some states also toll the statute of limitations for plaintiffs who are insane. See, e.g., Estate of Dearing v. Dearing, 646 F. Supp. 903, 910 (S.D. W. Va. 1986) ("Such tolling continues [under 
For purposes of the following discussion, three terms need to be defined: discovery rule, actual notice, and constructive notice. The discovery rule tolls the statute of limitations until the plaintiff knew of the alleged fraud or should have known had she exercised reasonable diligence. $^{22}$ Actual notice, as the phrase implies, exists when a plaintiff actually realizes that she has a cause of action. Constructive notice, or inquiry notice, ${ }^{23}$ exists when there are sufficient warning signs to make a reasonable person suspicious. ${ }^{24}$

\section{a. Fraudulent Concealment}

Statutes of limitations are often tolled because the defendant has fraudulently concealed the cause of action from the plaintiff. The Supreme Court provided the rationale for tolling statutes of limitations in cases of fraudulent concealment over a century ago in Bailey v. Glover, when it explained that statutes of limitations

were enacted to prevent frauds; to prevent parties from asserting rights after the lapse of time had destroyed or impaired the evidence which would show that such rights never existed, or had been satisfied, transferred, or extinguished, if they ever did exist. To hold that by concealing a fraud, or by committing a fraud in a manner that it concealed itself until such time as the party committing the fraud could plead the statute of limitations to protect it, is to make the law which was designed to prevent fraud the means by which it is made successful and secure. ${ }^{25}$

Bailey provides the basis for over one hundred years of equitable tolling. Like all equitable doctrines, the goal of tolling is to achieve the purposes of the underlying statutes (in this case, the statute of limitations and the securities laws).

Courts are divided as to the requirements for the fraudulent concealment branch of equitable tolling. There are roughly three camps. First, in nonsecurities cases, some courts have held that the plaintiff must show both that the defendant fraudulently concealed the action and that the

West Virginia law] until the disability is lifted. In no event, however, can the tolling exceed twenty years."). In contrast, "[u]nder the doctrine of federal equitable tolling, courts generally have not permitted mental illness, even where rising to the level of insanity, to delay the statute of limitations from running." Ebrahimi v. E.F. Hutton \& Co., 852 F.2d 516, 521 (10th Cir. 1988). An exception has been noted where the mental disability is caused by the defendant. See Lopez v. Citibank, N.A., 808 F.2d 905, 907 (Ist Cir. 1987); Zeidler v. United States, 601 F.2d 527, 531 (10th Cir. 1979).

22. See, e.g., Estate of Dearing, 646 F. Supp. at 907.

23. The phrases "inquiry notice" and "constructive notice" are used interchangeably.

24. In the context of securities regulation, inquiry notice can be triggered by one of many events. See infra notes 230-35 and accompanying text.

25. Bailey v. Glover, 88 U.S. (21 Wall.) 342, 349 (1874). 
plaintiff acted with due diligence ${ }^{26}$ in trying to uncover the fraud. ${ }^{27}$ Second, because securities fraud is often self-concealing, many courts have held that additional fraudulent concealment is not necessary to toll the statute of limitations, noting that "[e]ven without affirmative acts on the part of defendants . . . a federal cause of action will accrue at the time when plaintiff in the exercise of reasonable diligence discovered or should have discovered the fraud of which he complains."28 Third, while many courts do not treat active and passive concealment differently, some do. The Seventh Circuit summarized the distinction between active and passive concealment in Rule 10b-5 cases, explaining that

[e]quitable tolling applies in two situations. First, the doctrine will toll the running of the statute of limitations where the fraud goes undiscovered even though the defendant does nothing to conceal it. The plaintiff, however, must exercise due diligence in attempting to uncover the fraud. In the second situation in which equitable tolling applies, the fraud goes undiscovered because the defendant has taken positive steps after commission of the fraud to keep it concealed. This type of fraudulent concealment tolls the limitations period until actual discovery by the plaintiff. ${ }^{29}$

In addition to this lack of consensus on whether a plaintiff's due diligence is required for equitable tolling, there are also varying standards for what constitutes due diligence. In general,

while the question of whether a plaintiff should have discovered the fraud is an objective one using the reasonable investor standard, "the determination of whether a plaintiff actually exercised reasonable diligence requires a more subjective inquiry focusing upon the circumstances of the particular case, including the existence of a fiduciary relationship, the nature of the fraud alleged, the opportunity to discover the fraud, and the subsequent actions of the defendants." 30

The appropriate standard for due diligence in Rule $10 \mathrm{~b}-5$ cases is discussed in Section IV.A. 2 below.

26. The phrases "due diligence" and "reasonable diligence" are used interchangeably. There is no meaningful distinction.

27. See, e.g., Rutledge v. Boston Woven Hose \& Rubber Co., 576 F.2d 248, 250 (9th Cir. 1978); Armbrister v. Roland Int'l Corp., 667 F. Supp. 802, 810 (M.D. Fla. 1987).

28. Cook v. Avien, Inc., 573 F.2d 685, 695 (1st Cir. 1978).

29. Suslick v. Rothschild Sec. Corp., 741 F.2d 1000, 1004 (7th Cir. 1984) (citing Tomera v. Galt, 511 F.2d 504, 509 (7th Cir. 1975)).

30. Rodriguez v. Banco Cent., 727 F. Supp. 759, 768 (D.P.R. 1989) (quoting Maggio v. Gerard Freezer \& Ice Co., 824 F.2d 123, 128 (1st Cir. 1987)). 


\section{b. Adverse Domination}

Another aspect of equitable tolling is adverse domination. Adverse domination may be seen as an equitable doctrine in and of itself, ${ }^{31}$ or as a basis for equitable tolling, like fraudulent concealment. Adverse domination holds that "where an action is brought on behalf of an entity which has been defrauded by persons who completely dominated and controlled it, the statute of limitations is tolled as to the controlling wrongdoers during the period of their domination and control."32 This often ineans that the statute of limitations is tolled until a trustee or receiver is placed in charge of the assets. ${ }^{33}$ The rationale behind adverse domination is that wrongdoers cannot be expected to initiate a cause of action against themselves. ${ }^{34}$

Adverse domination usually arises in the context of corporations charged with wrongdoing, where the shareholders seek to bring suit against the directors for breach of their fiduciary duties, through securities fraud or other illegal activities. In these cases, adverse domination is necessary to protect shareholders and creditors. ${ }^{35}$ The protection, however, is somewhat limited. For while it is relatively easy for corporate officers to conceal information that plaintiffs need to discover that they have a cause of action, ${ }^{36}$ adverse domination is difficult for the plaintiff to prove because he must show "full, complete and exclusive control in the directors or officers charged."37 Nevertheless, the doctrine is necessary because without tolling in adverse domination cases, directors who engage in illegal activities can effectively prevent a corporation from pursuing its rights against thein. ${ }^{38}$ Equitable principles guarantee that wrongdoers do not gain from their illegal activities.

\section{Equitable Estoppel}

The doctrine of equitable estoppel prevents a defendant's arguing "the statute of linitations if actions by him have caused a plaintiff to fail

31. See Resolution Trust Corp. v. Kerr, 804 F. Supp. 1091, 1094 (W.D. Ark. 1992).

32. Armstrong v. McAlpiu, 699 F.2d 79, 87 (2d Cir. 1983).

33. See Michelsen v. Penney, 135 F.2d 409, 416 \& n.2 (2d Cir. 1943).

34. FDIC v. Manatt, 723 F. Supp. 99, 105 (E.D. Ark. 1989); FDIC v. Hudson, 673 F. Supp. 1039, 1042 (D. Kan. 1987); FDIC v. Bird, 516 F. Supp. 647, 651 (D.P.R. 1981); see also Resolution Trust Corp. v. International Ins. Co., 770 F. Supp. 300, 305 (E.D. La. 1991).

35. FDIC v. Farris, 738 F. Supp. 444, 445 (W.D. Okla. 1989).

36. See Federal Sav. \& Loan Ins. Corp. v. Williams, 599 F. Supp. 1184, $1193-94$ n. 12 (D. Md. 1984). Williams also suggests that due diligence should not be required where there is a fiduciary relationship between shareholders and the board. Id. at 1194-95.

37. Armstrong v. McAlpin, 699 F.2d 79, 87 (2d Cir. 1983) (quoting Payne v. Ostrus, 50 F.2d 1039, 1042 (8th Cir. 1931)).

38. See Resolution Trust Corp. v. Interstate Fed. Corp., 762 F. Supp. 905, 909-10 (D. Kan. 1991) (finding statute of limitations tolled until culpable directors no longer held majority). 
to file his complaint within the prescribed period."39 Referring to the doctrine's common law roots, Justice Black called equitable estoppel a "principle of law, older than the country itself." 40 Like equitable tolling, equitable estoppel is read into a statute by the courts. The doctrine's "application is wholly independent of the limitations period itself and takes its life, not from the language of the statute, but from the equitable principle that no man will be permitted to profit from his own wrongdoing in a court of justice."41 Equitable estoppel applies when a plaintiff "recognize[s] the basis for suit, but the wrongdoer prevails upon [him] to forego enforcing his right until the statutory time has lapsed."42

Courts are most likely to apply equitable estoppel when defendants enter settlement negotiations prior to the running of the statute of limitations. ${ }^{43}$ As one court put it:

Equitable e]stoppel arises where one, by his conduct, lulls another into a false security, and into a position he would not take only because of such conduct. Estoppel, in the event of a disputed claim, arises where one party by words, acts, and conduct led the other to believe that it would acknowledge and pay the claim, if, after investigation, the claim were found to be just, but when, after the time for suit had passed, breaks off negotiations and denies liability and refuses to pay. ${ }^{44}$

In the context of securities fraud, an unscrupulous promoter may privately admit (and perhaps apologize for) misleading an investor, make apparently sincere efforts to make amends, then plead a statute of limitations defense when the statutory period expires. Without equitable estoppel, such a strategy would succeed, deceiving the victims twice.

Because the courts generate equitable doctrines themselves, judges generally have some latitude when employing equitable estoppel. However, some well-accepted conditions apply. First, equitable estoppel requires an affirmative act by the defendants "which induces the Plaintiffs to refrain from timely bringing suit."45 Second, equitable estoppel requires reliance on the defendants' representation, for, without reliance, the defendant's conduct cannot mislead the plaintiff. ${ }^{46}$ Finally, the fraud that influenced the plaintiff to delay bringing suit must have

39. Gieringer v. Silverman, 731 F.2d 1272, 1278 (7th Cir. 1984); accord Bomba v. W.L. Belvidere, Inc., 579 F.2d 1067, 1070-71 (7th Cir. 1978).

40. Glus v. Brooklyn E. Dist. Terminal, 359 U.S. 231, 234 (1959).

41. Bomba, 579 F.2d at 1070.

42. Cook v. Deltona Corp., 753 F.2d 1552, 1563 (11th Cir. 1985) (quoting Aldrich v. McCulloch Properties, Inc., 627 F.2d 1036, 1043 n.7 (10th Cir. 1980)).

43. See Gieringer, 731 F.2d at 1278.

44. Bomba, 579 F.2d at 1071 (quoting McWaters \& Bartlett v. United States, 272 F.2d 29I, 296 (10th Cir. 1959)).

45. Estate of Dearing v. Dearing, 646 F. Supp. 903, 907 (S.D. W. Va. 1986).

46. See Merrill Lynch, Pierce, Fenner \& Smith, Inc. v. Georgiadis, 724 F. Supp. 120, 124 (S.D.N.Y. 1989); Anisfeld v. Cantor Fitzgerald \& Co., 631 F. Supp. 1461, 1467 (S.D.N.Y. 1986). 
occurred before the statute of limitations ran out. ${ }^{47}$

The primary distinction between equitable tolling and equitable estoppel is that while tolling is "invoked in cases where the plaintiff is ignorant of his cause of action because of the defendant's fraudulent concealment, equitable estoppel is invoked in cases where the plaintiff knew of the existence of his cause of action but the defendant's conduct caused him to delay in bringing his lawsuit."48 Equitable tolling and equitable estoppel "are mutually exclusive because one requires proof that the plaintiff knew he had a claim, whereas the other requires proof that the plaintiff did not know of the facts establishing his claim."49 Thus, as a rule, only one equitable doctrine will be applied in any given case.

Procedurally, however, these equitable doctrines are similar. The plaintiff bears the burden of proving the applicability of both equitable tolling and equitable estoppel. ${ }^{50}$ Additionally, although judges typically resolve equitable issues, courts have generally treated equitable tolling and equitable estoppel as questions of fact for the jury. ${ }^{51}$

\section{II}

The Current State of the Law Regarding Equitable Tolling AND EQUITABLE ESTOPPEL IN Rule 10b-5 CASES

\section{A. The Law Before Lampf}

The most potent weapon in the Exchange Act's arsenal against securities fraud was not intended by Congress at all. Rule 10b-5, ${ }^{52}$ promulgated by the SEC in 1942 under section $10(\mathrm{~b})^{53}$ of the 1934 Act,

47. See Cook v. Deltona Corp., 753 F.2d 1552, 1563 (11th Cir. 1985).

48. Cerbone v. International Ladies' Garment Workers' Union, 768 F.2d 45, 49-50 (2d Cir. 1985). Some courts have misapprehended this distinction, reasoning that "[e]quitable estoppel may also arise when affirmative fraudulent statements are made which conceal from the plaintiff facts essential to make out the cause of action." Renz v. Beeman, 589 F.2d 735, 750 (2d Cir. 1978), cert. denied, 444 U.S. 834 (1979).

49. Armbrister v. Roland Int'l Corp., 667 F. Supp. 802, 809 (M.D. Fla. 1987).

50. Rodriguez v. Banco Cent., 727 F. Supp. 759, 764 (D.P.R. 1989).

51. See Durham v. Business Management Assocs., 847 F.2d 1505, 1509-10 (11th Cir. 1988); see also Cook v. Avien, Inc. 573 F.2d 685, 697 n.27 (1st Cir. 1978).

52. Rule $10 \mathrm{~b}-5$ reads:

It shall be unlawful for any person, directly or indirectly, by the use of any means or instrumentality of interstate commerce, or of the mails or of any facility of any national securities exchange,

(a) To employ any device, scheme, or artifice to defraud,

(b) To make any untrue statement of a material fact or to omit to state a material fact necessary in order to make the statements made, in the light of the circumstances under which they were made, not misleading, or

(c) To engage in any act, practice, or course of business which operates or would operate as a fraud or deceit upon any person, in connection with the purchase or sale of any security.

17 C.F.R. $\S 240.10 b-5$ (1992).

53. Section $10(\mathrm{~b})$ provides, in pertinent part: 
now provides private victims a highly effective mechanism to sue their wrongdoers. ${ }^{54}$ However,

[t] he private right of action under [section 10(b)] is a judicial, rather than a legislative creation. Nowhere in the Securities Exchange Act of 1934 can be found an express private civil remedy for the violation of its terms. Indeed, a perusal of the legislative history surrounding the promulgation of section $10(\mathrm{~b})$ fails to reveal any indication that Congress contemplated a private right of action. Moreover, in adopting Rule 10b-5 in 1942, the Commission did not address, and in fact did not consider, the question of private civil remedies under the provision. ${ }^{55}$

The private cause of action under section 10(b) was first recognized by the federal courts in $1946 .^{56}$ The origin of this private cause of action has since been described as everything from the "judicial oak which has grown from little more than a legislative acorn"s7 to "a genie sired solely by the judiciary."58 Despite its unusual beginnings, the private cause of action is now well established. ${ }^{59}$ However, because Congress did not intend to create the private cause of action, it did not provide a statute of limitations.

Because there was no statutory limitations period for Rule $10 \mathrm{~b}-5$ cases, federal courts borrowed the most analogous statute of limitations from the state where the violation occurred. Holmberg v. Armbrecht ${ }^{60}$ laid the foundation for this principle. ${ }^{61}$ Holmberg involved the Federal

\footnotetext{
It shall be unlawful for any person, directly or indirectly, by the use of any means or instrumentality of interstate commerce or of the mails, or of any facility of any national securities exchange-

...

(b) To use or employ, in connection with the purchase or sale of any security registered on a national securities exchange or any security not so registered, any manipulative or deceptive device or contrivance in contravention of such rules and regulations as the Commission may prescribe as necessary or appropriate in the public interest or for the protection of investors.
}

15 U.S.C. $\$ 78 \mathrm{j}$ (1988).

54. The Supreme Court has observed that $\S 10(\mathrm{~b})$ and Rule $10 \mathrm{~b}-5$ "may well be the most litigated provisions in the federal securities laws." SEC v. National Sec., Inc., 393 U.S. 453, 465 (1969).

55. SEC v. Materia, 745 F.2d 197, 202 (2d Cir. 1984) (citing S. REP. No. 792, 73d Cong., 2d Sess. 5-6 (1934); Securities Exchange Act Release No. 3230, 7 Fed. Reg. 3804 (May 21, 1942)), cert. denied, 471 U.S. 1053 (1985); Note, Implied Liability Under the Securitics Exchange Act, 61 HARV. L. REV. 858,861 (1948).

56. See Kardon v. National Gypsum Co., 69 F. Supp. 512, 513-14 (E.D. Pa. 1946).

57. Blue Chip Stamps v. Manor Drug Stores, 421 U.S. 723, 737 (1975).

58. In re Data Access Sys. Sec. Litig., 843 F.2d 1537, 1547 (3d Cir.) (en banc), cert. denied, 488 U.S. 849 (1988).

59. See Herman \& MacLean v. Huddleston, 459 U.S. 375, 380-81 \& n.10 (1983) (confirming that the private right of action under Rule 10b-5 is "simply beyond peradventure"); Superintendent of Ins. v. Bankers Life \& Casualty Co., 404 U.S. 6, 13 n.9 (1971).

60. 327 U.S. 392 (1946).

61. See Harold S. Bloomenthal, The Statute of Limitations and Rule 10b-5 Claims: A Study in Judicial Lassitude, 60 U. CoLo. L. REv. 235, 239 (1989). 
Farm Loan Act, not securities fraud, but it established two general principles regarding statutes of limitations for federally created rights. First, if Congress explicitly enacts a time limitation, this "Congressional statute of limitation is definitive." tions period for actions at law, "the silence of Congress has been interpreted to mean that it is federal policy to adopt the local law of limitation."63 The lower courts relied on this second proposition in Rule $10 \mathrm{~b}-5$ cases and applied the statute of limitations of the most analogous law of the state where the violation occurred. The Second Circuit in Fischman v. Raytheon Manufacturing Co. was one of the first appellate courts to do so. ${ }^{64}$ The remaining circuits soon followed suit, and this became the well-established rule across all circuits. ${ }^{65}$ Without endorsing the process directly, by dechining to address the issue the Supreme Court tacitly confirmed the process of borrowing analogous state statutes of limitations for federal securities fraud cases. ${ }^{66}$

The major problem in applying this standard was determining which state law was indeed the most analogous. In some circuits, commonality of purpose between federal securities laws and state laws determined which state law was analogous. ${ }^{67}$ Other jurisdictions complicated this test. For exainple, the Eighth Circuit employed an analysis that considered both commonality of purpose and similarity of defenses between the federal and state statutes. ${ }^{68}$

The circuits split as to whether applying the most analogous state law required the imposition of the state's blue sky law ${ }^{69}$ or the common

62. Holmberg, 327 U.S. at 395 (citing Herget v. Central Nat'l Bank \& Trust Co., 324 U.S. 4 (1945)).

63. Id. (citing Campbell v. City of Haverhill, 155 U.S. 610 (1895); Chattanooga Foundry \& Pipe Works v. City of Atlanta, 203 U.S. 390 (1906); Rawlings v. Ray, 312 U.S. 96 (1941)).

64. Fischman v. Raytheon Mfg. Co., 188 F.2d 783, 787 (2d Cir. 1951).

65. Corwin v. Marney, Orton Invs., 843 F.2d 194, 198 (5th Cir.), cert. denied, 488 U.S. 924 (1988); Suslick v. Rothschild Sec. Corp., 741 F.2d 1000, 1004 (7th Cir. 1984); Vucinich v. Paine, Webber, Jackson \& Curtis, Inc., 739 F.2d 1434, 1436 (9th Cir. 1984); Kennedy v. Tallant, 710 F.2d 711, 716 (11th Cir. 1983); Armstrong v. McAlpin, 699 F.2d 79, 86 (2d Cir. 1983); Herm v. Stafford, 663 F.2d 669, 677 (6th Cir. 1981); Sharp v. Coopers \& Lybrand, 649 F.2d 175, 191 (3d Cir. 1981), cert. denied, 455 U.S. 938 (1982); Buder v. Merrill Lynch, Pierce, Fenner \& Smith, Inc., 644 F.2d 690, 691 (8th Cir. 1981); O'Hara v. Kovens, 625 F.2d 15, 17 (4th Cir. 1980), cert. denied, 449 U.S. 1124 (1981); Wachovia Bank \& Trust Co., N.A. v. National Student Mktg. Corp., 650 F.2d 342, 346 (D.C. Cir. 1980), cert. denied, 452 U.S. 954 (1981); Cook v. Avien, Inc., 573 F.2d 685, 694 (Ist Cir. 1978); deHaas v. Empire Petroleum Co., 435 F.2d 1223, 1225 (10th Cir. 1970).

66. See Ernst \& Ernst v. Hochfelder, 425 U.S. 185, 210 n.29 (1976).

67. See, e.g., O'Hara, 625 F.2d at 18.

68. See Vanderboom v. Sexton, 422 F.2d 1233, 1240 (8th Cir.), cert. denied, 400 U.S. 852 (1970).

69. Blue Sky Law:

A popular name for acts providing for the regulation and supervision of investment companies, for the protection of the community from investing in fraudulent companies. A law intended to stop the sale of stock in fiy by night concerns, visionary oil wells, distant gold mines, and other like fraudulent exploitations.

BLACK'S LAW Dictionary 218 (4th ed. 1951). 
law fraud limitations period on Rule $10 \mathrm{~b}-5$ plaintiffs. ${ }^{70}$ The choice between these two statutes of limitations was often significant because blue sky limitations periods are generally two years, while the common law fraud limitations periods generally run from three to six years. ${ }^{71}$ For example, federal courts sitting im Connecticut applied the statute of limitations from the Connecticut Uniform Securities Act, which forbids initiating a suit "more than two years after tlie contract of sale."72 Similarly, federal courts in Georgia applied the two-year limitations period from the Georgia blue sky law. ${ }^{73}$ Federal courts sitting in South Carolina applied the state's three-year statute of limitation from its blue sky law. ${ }^{74}$ In contrast, federal courts sitting in Olio applied the state's four-year common law fraud limitation to Rule $10 \mathrm{~b}-5$ claims. ${ }^{75}$ The nonuniformity lit notable extremes, with different limitations periods applied in cases arising in the same state. ${ }^{76}$ These distinctions were significant, ranging from one year in Louisiana ${ }^{77}$ and Maryland ${ }^{78}$ to ten years in Tennessee. ${ }^{79}$

70. Dennis J. Block \& Nancy E. Barton, Securities Litigation: Statute of Limitations in Private Actions Under Section 10(b)—A Proposal for Achieving Uniformity, 7 SEC. REg. L.J. 374, 375-76 (1980).

71. 2 Thomas L. Hazen, Treatise on the Law of Securities Regulation $\S 13.8$, at 130 (2d ed. 1990); see also Gayla D. Lee, Note, Securities, 13 CREIGHTON L. REV. 1436, 1445-46 (1980) (pointing out that common law fraud actions tend to have longer limitations periods than do blue sky actions).

72. Clute v. Davenport Co., 584 F. Supp. 1562, 1577 (D. Conn. 1984) (borrowing from what is now Conn. Gen. STat. ANn. § 36-498(f) (West Supp. 1992), then at § 36-498(e)); Maiden v. Biehl, 582 F. Supp. 1209, 1214 \& n.4 (S.D.N.Y. 1984).

73. Friedlander v. Troutman, Sanders, Lockerman \& Ashmore, 788 F.2d 1500, 1506 (11th Cir. 1986) (borrowing from GA. CODE ANN. § 10-5-14(d) (Harrison 1991)); Diamond v. Lamotte, 709 F.2d 1419, 1422 (11th Cir. 1983).

74. Mid-Carolina Oil, Inc. v. Klippel, 526 F. Supp. 694, 697 (D.S.C. 1981) (borrowing from S.C. CoDE ANN. § 35-1-1530 (Law. Co-op. 1987)), aff'd without op., 673 F.2d 1313 (4th Cir.), cert. denied, 457 U.S. 1107 (1982).

75. Marx v. Centran Corp., 747 F.2d 1536, 1551 (6th Cir. 1984) (borrowing from OHIo REv. CODE ANN. $\S 2305.09$ (Anderson 1991)), cert. denied, 471 U.S. 1125 (1985).

76. In Tennessee, for example, the Eastern District employed a one-year/two-year limitations/ repose formula from the state's blue sky law. See Montcastle v. American Health Sys., Inc., 702 F. Supp. 1369, 1372 (E.D. Tenn. 1988). In contrast, the Western District used a three-year limitation period for common law fraud. See Media Gen., Inc. v. Tanner, 625 F. Supp. 237, 247 (W.D. Tenn. 1985). Finally, the Middle District could not make up its mind, applying each of the two limitation periods at different times without explanation. See Nichols v. Merrill Lynch, Picrce, Fenner \& Smith, 706 F. Supp. 1309, 1320-21 (M.D. Tenn 1989) (using three-year statute of limitations); Logan v. Ledford, 699 F. Supp. 141, 144 (M.D. Tenn. 1988) (applying one-year/two-year formula); see also David S. Ruder \& Neil S. Cross, Limitations on Civil Liability Under Rule 10b-S, 1972 Duke L.J. $1125,1142-50$ (discussing lack of consistency within circuits where statutes of limitations varied).

77. See Weiser v. Shwartz, 286 F. Supp. 389, 391 (E.D. La. 1968) (applying Louisiana's general one-year limit for torts). But see Dupuy v. Dupuy, 551 F.2d 1005, 1023-24 n.31 (5th Cir.) (applying a two-year limit from Louisiana blue sky law), cert. denied, 434 U.S. 911 (1977).

78. See O'Hara v. Kovens, 625 F.2d 15, 17 (4th Cir. 1980), cert. denied, 449 U.S. 1124 (1981).

79. See Denny v. Performance Sys., Inc. [1971-1972 Transfer Binder] Fed. Sec. L. Rep. (CCH) If 93,387, at 91,981 (M.D. Tenn. 1971). However, the 10-year fraud limitations period was subsequently shortened to three years by a decision of the Tennessee Supreme Court. See Media Gen., Inc v. Tanner, 625 F. Supp. 237, 246 (W.D. Tenn. 1985). 
The one doctrine that applied regardless of the state limitations period was federal equitable tolling. Although Guaranty Trust Co. v. York $^{80}$ held that federal courts sitting in diversity should apply tlie state statute of limitations, Holmberg clarified that when there is a federal question involved, courts must use the federal equitable tolling doctrine. ${ }^{81}$ Thus, the circuit courts of appeals have consistently held that wlien using state statutes of limitations for Rule 10b-5 cases, tolling is still a matter of federal law. ${ }^{82}$

Even wlien the borrowed state statute of limitations contained an absolute bar, ${ }^{83}$ the statute of repose was tolled in Rule $10 \mathrm{~b}-5$ suits. $^{84}$ The

80. 326 U.S. $99,108-09$ (1945).

81. Holmberg v. Armbrecht, 327 U.S. 392, 397 (1946).

82. Durham v. Business Management Assocs., 847 F.2d 1505, 1508 (11th Cir. 1988) ("While state law governs the limitations period applicable to a section 10(b) action, federal law governs when the limitations period begins to run."); Kennedy v. Josephthal \& Co., 814 F.2d 798, 802 (1st Cir. 1987); Semegen v. Weidner, 780 F.2d 727, 733 (9th Cir. 1985); Marx v. Centran Corp., 747 F.2d 1536, 1551 (6th Cir. 1984), cert. denied, 471 U.S. 1125 (1985); Suslick v. Rothschild, 741 F.2d 1000, 1004 (7th Cir. 1984); Kennedy v. Tallant, 710 F.2d 711, 716 (11th Cir. 1983).

Although state law had been held to control tolling in some cases, see Board of Regents v. Tomanio, 446 U.S. 478, 483-86 (1980) (discussing borrowing of state law statutes of limitation in $\S 1983$ civil rights cases), this doctrine was never important for securities litigation because the state and federal tolling provisions often coincided. See, e.g., Armstrong v. McAlpin, 699 F.2d 79, 86-87 (2d Cir. 1983) ("[T] he onset periods for actions such as this are substantially the same in [New York law and federal law]."); Aldrich v. McCulloch Properties, Inc., 627 F.2d 1036, 1041 (10th Cir. 1988) (comparing tolling under federal and Colorado law). Even if courts had applied the state doctrines on equitable tolling, claims brought under Rnle $10 \mathrm{~b}-5$ would have been tolled for fraudulent concealment in many jnrisdictions. See, e.g., GA. CoDE ANN. § 9-3-96 (Harrison 1991) (tolling for fraudulent concealment allowed for all statutes of limitations in Georgia); L.C.L. Theatres, Inc. v. Columbia Pictures Indus., 566 F.2d 494, 496-97 (5th Cir. 1978) (making tolling available in Texas); London v. Green Acres Trust, 765 P.2d 538, 545 (Ariz. Ct. App. 1988) (allowing tolling in Arizona). But see infra note 83 (listing some states which have statutes of repose).

83. For example, federal courts in Arkansas borrowed the blue-sky limitations period, ARK. CODE ANN. § 23-42-106(f) (Michie 1987), which bars suit "after five (5) years from the effective date of the contract of sale," id. See Pinney v. Edward D. Jones \& Co., 718 F. Supp. 1419, 1421 (W.D. Ark. 1989). That limitations period is a statnte of repose. Martin v. Pacific Ins. Co., 431 S.W.2d 239, 240 (Ark. 1968) (limitations period was then codified at ARK. STAT. ANN. § 671256(e)). For other statutes of repose, see King v. Gandolfo, 714 F. Supp. 1180, 1181 (M.D. Fla. 1989) (borrowing the Florida limitations period, currently codified at FLA. STAT. ANN. \& 95.11(4)(e) (West Supp. 1993)); Wilder v. Meyer, 779 F. Supp. 164, 167-68 (S.D. Fla. 1991) (construing $\S 95.11$ (4)(e) to contain a five-year statute of repose); O'Hara v. Kovens, 625 F.2d 15, 17-18 (4th Cir. 1980) (borrowing Maryland limitations period, currently codified at MD. CORPS. \& Ass'NS CODE ANN. § 11-703(f) (1993)), cert. denied, 449 U.S. 1124 (1981); Morley v. Cohen, 610 F. Supp. 798, 820 (D. Md. 1985) (construing $\$ 11-703(\mathfrak{f})$ to contain a three-year statute of repose); Estate of Dearing v. Dearing, 646 F. Supp. 903,907 (S.D. W. Va. 1986) (borrowing West Virginia limitations period, currently codified at W. VA. CODE $\$ 32-4-410($ e) (1992)); Brumbaugh v. Princeton Partners, 766 F. Supp. 497,500 (S.D. W. Va. 1991) (construing $\S 32-4-410$ (e) to contain a three-year statute of repose), aff'd, 985 F.2d 157 (4th Cir. 1993).

84. See, e.g., Hudak v. Economic Research Analysts, Inc., 499 F.2d 996, 1000 \& n.5 (5th Cir. 1974) ("[O]ur acceptance of the two year term imposed by [Florida law] in no way constitutes an adoption of the statutory provision that the time be measured from the date of sale rather than the date of discovery."), cert. denied, 419 U.S. 1122 (1975); Estate of Dearing, 646 F. Supp. at 908 (applying federal equitable tolling, following Kirschner v. Cable/Tel. Corp., 576 F. Supp. 234 (E.D. Pa. 1983), in spite of the West Virginia statute of repose). 
rationale for not applying a statute of repose even in those states which had one was provided by the Supreme Court in DelCostello $v$. International Brotherhood of Teamsters:"85 "State legislatures do not devise their limitations periods with national interests in mind, and it is the duty of the federal courts to assure that the importation of state law will not frustrate or interfere with the implementation of national policies."86

The process of borrowing state limitations periods became increasingly unpalatable in securities fraud cases. First, reliance on the most analogous state statute meant that the statute of limitations was subject to change if the substantive law elements of a Rule 10b-5 violation changed in a way that rendered another state statute more analogous. For example, when the Court articulated a scienter requirement for Rule 10b-5 violations in Ernst \& Ernst v. Hochfelder, ${ }^{87}$ confusion arose because state common law fraud statutes started to look inore analogous than state blue sky laws, which generally contained only a negligence standard. ${ }^{88}$

Second, the nonuniformity among state statutes of limitations created a slew of problems for both judges and litigants. Disparate limitations periods created incentives for forum-shopping. ${ }^{89}$ Additionally, determining which of the myriad of possible state statutes of limitations should be applied needlessly consumed judicial resources. Judge Easterbrook referred to the absence of a uniform limitations period as "one tottering parapet of a ramshackle edifice. Deciding what features of state periods of limitation to adopt for which federal statutes wastes untold hours."90 An extreme example of this waste occurred in a section 10(b) class action suit in the Southern District of New York in which the judge had to apply limitations periods of one, two, three, or four years to similar claims brought by plaintiffs from twenty-six different states. ${ }^{91}$

85. 462 U.S. 151 (1983).

86. Id. (quoting Occidental Life Ins. Co. v. EEOC, 432 U.S. 355,367 (1977)).

87. 425 U.S. 185 (1976).

88. Lee, supra note 71 , at $1448-49$. Similar problems resulted when states changed their statutes of limitations. For example, when Texas expanded its statute of limitations for fraud aetions from two to four years, Rule 10b-5 claims were resurrected. See Sioux, Ltd., Sec. Litig. v. Coopers \& Lybrand, 901 F.2d 51, 52-53 (applying Texas statute of limitations to find 10b-5 suit time-barred), superseded by 914 F.2d 61, 63-64 (5th Cir. 1990) (reversing earlier decision because the Texas Supreme Court held that certain legislative amendments had lengtlened the statute of limitations for fraud).

89. 3 Louis Loss, Securities Regulation $1771-72$ (2d ed. 1961); Stephen H. Schulman, Statutes of Limitation in 10b-5 Actions: Complication Added to Confusion, 13 WAYNE L. REV. 635, 648 (1967) ("The end result under current limitations doctrine inevitably remains the encouragement of forum shopping ....").

90. Norris v. Wirtz, 818 F.2d 1329, 1332 (7th Cir.), cert. denied, 484 U.S. 943 (1987); see also Short v. Belleville Shoe Mfg. Co., 908 F.2d 1385, 1389 (7th Cir. 1990) ("Lawyers and courts alike devote untold hours to identifying proper state analogies ...."), cert. denied, 111 S. Ct. 2887 (1991).

91. Kronfeld v. Advest, Inc., 675 F. Supp. 1449, 1457.58 \&'n.21 (S.D.N.Y. 1987); see also In 
Finally, nonuniformity created confusion for plaintiffs who were uncertain as to which limitations period governed their case. ${ }^{92}$ By the late 1980s, the cries for uniformity became a chorus, with the American Bar Association, scholars and many courts all singing in tune. ${ }^{93}$

The Third Circuit took up the cause of uniformity in In re Data Access Systems Securities Litigation. ${ }^{94}$ Data Access extolled the virtues of uniformity in the application of statutes of himitations for federally created rights. The court rehed heavily on Agency Holding Corp. v. MalleyDuff \& Associates, Inc., ${ }^{95}$ where the Supreme Court adopted a uniform statute of limitations for Racketeering Influenced and Corrupt Organizations Act (RICO) actions. In Agency Holding, the Court provided three justifications for uniform statutes of limitations. First, the Court wanted to avoid the "uncertainty and time-consuming litigation" necessary when using analogous state law. ${ }^{96}$ Second, unform statutes of limitations promote fairness by treating all litigants similarly and, therefore, eliminating the incentive for forum-shopping. ${ }^{97}$ Third, the Court reasoned that there was no appropriate state analog for the federal RICO statute. ${ }^{98}$ The first two rationales clearly applied equally to Rule $10 \mathrm{~b}-5$ suits, and it was becoming increasingly difficult to claim that one state statute was more analogous than another.

Once the Third Circuit decided that a uniform statute of limitations was necessary for federal securities fraud, the only remaining question was what that limitations period should be. Concluding that federal law should govern any newly created uniform statute of limitations, the Third Circuit set out to determine which federal limitations period to borrow. The Third Circuit looked to the 1934 Exchange Act to find an appropriate statute of limitations for Rule 10b-5 actions. ${ }^{99}$ The 1934 Act lays out express statutes of limitations for several violations: section $9(e)^{100}$ for manipulation of security prices, section $16(b)^{101}$ for short-

re National Student Mktg. Litig., [1981 Transfer Binder] Fed. Sec. L. Rep. (CCH) I 97,926, at 90,709 (D.D.C. 1981) (noting the possibility of applying 34 different limitations periods to $\S 10(\mathrm{~b})$ claims).

92. See In re Data Access Sys. Sec. Litig., 843 F.2d 1537, 1543 (3d Cir.) (en banc), cert. denied, 488 U.S. 849 (1988).

93. Committee on Fed. Regulation of Sec., A.B.A., Report of the Task Force on Statute of Limitations for Implied Actions, 41 Bus. LAw. 645, 645 (1986); see also Short, 908 F.2d at 1389 (noting calls for reform "[w]ith a unanimity unmatched in any other corner of securities law").

94. 843 F.2d 1537 (3d Cir.) (en banc), cert. denied, 488 U.S. 849 (1988).

95. 483 U.S. 143, 156 (1987).

96. Id. at 150 (quoting Wilson v. Garcia, 471 U.S. 261, 272 (1985)).

97. Id. at 154 .

98. Id. at 152 .

99. In re Data Access Sys. Sec. Litig., 843 F.2d 1537, 1545 (3d Cir.) (en banc), cert. denied, 488 U.S. 849 (1988).

100. 15 U.S.C. $\S 780(\mathrm{e})(1988)$.

101. Id. $\S 78 \mathrm{p}(\mathrm{b})$. 
swing profits, section $18(\mathrm{c})^{102}$ for misleading statements in filed documents, and section $29(\mathrm{~b})^{103}$ for contract provisions violating the Act or regulations promulgated under it. The Third Circuit reasoned that these provisions shared the same general purposes of Rule 10b-5 of deterring fraud and compensating victims. ${ }^{104}$ With the exception of section $16(\mathrm{~b})$, which has a two-year statute of repose, ${ }^{105}$ all of the express statutes of limitations in the Exchange Act use a one-year/three-year formula. ${ }^{106}$ This formula requires that a cause of action be brought both within one year after discovery of the relevant facts and within three years after the cause of action has accrued. The Third Circuit adopted a one-year/ three-year formula in language closely similar to that of section $9(\mathrm{e}) .^{107}$ No case before Data Access had applied this formula to a Rule 10b-5 action. ${ }^{108}$ Most importantly for this Comment, the Third Circuit had previously acknowledged that section 9's three-year outer limit was absolute, not subject to tolling. ${ }^{109}$

The Data Access decision spawned a split among the circuits. The

102. Id. $\S 78 \mathrm{r}(\mathrm{c})$.

103. 15 U.S.C. $\$ 78 \mathrm{cc}$ (b) (Supp. III 1992).

104. In re Data Access Sys. Sec. Litig., 843 F.2d 1537, 1548 (3d Cir.) (en banc), cert. denied, 488 U.S. 849 (1988).

105. Although $\S 16(\mathrm{~b})$ is often called a statute of repose, it contains a modified tolling aspect. Section 16(b) sets out a two-year limitations period, but $\S 16($ a) also requires that insiders report all securities transactions to the SEC. Some circuits have held that the two-year period is tolled until the insider discloses his trades to the Commission. Whittaker v. Whittaker Corp., 639 F.2d 516, 528 (9th Cir.), cert. denied, 454 U.S. 1031 (1981).

106. For text and comparison of sections, see infra notes 127-30 and aceompanying text. Data Access was decided before Congress enacted $\$ 20 \mathrm{~A}$ with its five-year statute of limitations, Sce infra note 124 and accompanying text. The Second and Seventh Circuits later refused to borrow the § $20 \mathrm{~A}$ statute of limitations for Rule 10b-5. Ceres Partners v. GEL Assocs., 918 F.2d 349, 362-63 (2d Cir. 1990); Short v. Belleville Shoe Mfg. Co., 908 F.2d 1385, 1390-92 (7th Cir. 1990), cert. denied, 111 S. Ct. 2887 (1991). The Seventh Circuit did so in part because it did not want to deviate from what the Third Circuit had done in Data Access. Id. at 1390-91.

107. Data Access, 843 F.2d at 1550.

108. Keith Verges, The Statute of Limitations in Rule 106-5 Cases: Lots of Action, but What Progress?, BARRISTER, Spring 1992, at 35, 36.

109. Walck v. American Stock Exch., 687 F.2d 778, 792 (3d Cir. 1982), cert. denied, 461 U.S. 942 (1983). 
Second ${ }^{110}$ and Seventh Circuits ${ }^{111}$ adopted the Third Circuit's one-year/ three-year rule. The Ninth, ${ }^{112}$ Tenth, ${ }^{113}$ and Eleventh ${ }^{114}$ Circuits declined to follow Data Access and held fast to borrowing the most analogous state statute of limitations. Thus, despite the Third Circuit's best efforts, a uniform national statute of limitations for Rule 10b-5 cases did not evolve among the circuits.

\section{B. The Lampf Decision}

The Supreme Court moved to resolve the split among the circuits in Lampf, Pleva, Lipkind, Prupis \& Petigrow v. Gilbertson. ${ }^{115}$ The Court first explained the state law-borrowing doctrine. Writing for four of the Court's nine members, ${ }^{116}$ Justice Blackmun acknowledged that "the usual rule ... when Congress has failed to provide a statute of limitations for a federal cause of action" is to borrow "the local time limitation most analogous to the case at hand."117 Although there is a presumption that "Congress ordinarily intends by its silence that we borrow state law," "118 departure from the state law-borrowing doctrine is warranted when state law is " 'at odds with the purpose or operation of federal substantive law.' "119 The Court articulated a three-part test for determining whether the state law-borrowing doctrine is appropriate. First, a court should determine the necessity of maintaining a umiform statute of limitations, considering such factors as predictability and judicial econ-

110. The Second Circuit followed Data Access in Ceres, 918 F.2d at 360. Prior to Ceres, federal courts sitting in New York applied the state's limitation period for common law fraud which contains a form of equitable tolling. See, e.g., Armstrong v. McAlpin, 699 F.2d 79, 86-87 (2d Cir. 1983). New York law provides that "[t]he following actions must be commenced within six years: ... an action based upon fraud; the time within which the action must be commenced shall be computed from the time the plaintiff or the person under whom he claims discovered the fraud, or could with reasonable diligence have discovered it." N.Y. ClV. PRAC. L. \& R. § 213 (McKinney 1990). Further, section 203(f) provides that:

[W] when facts were discovered or from the time when facts could with reasonable diligence have been discovered, or from either of such times, the action must be commenced within two years after such actual or imputed discovery or within the period otherwise provided, computed from the time the cause of action accrued, whichever is longer.

Id. $\S 203(\mathrm{~g})$.

111. Short v. Belleville Shoe Mfg. Co., 908 F.2d 1385, 1390-91 (7th Cir. 1990), cert. denied, 111 S. Ct. 2887 (1991).

112. Nesbit v. McNeil, 896 F.2d 380, 384 (9th Cir. 1990).

113. Bath v. Bushkin, Gaims, Gaines \& Jonas, 913 F.2d 817, 818 (10th Cir. 1990).

114. Smith v. Duff \& Phelps, Inc., 891 F.2d 1567, $1569-70$ (11th Cir. 1990).

115. $111 \mathrm{~s}$. Ct. 2773 (1991).

116. Justice Scalia served as the fifth vote for the majority opinion but declined to sign on to Justice Blackmun's explanation of the state-borrowing doctrine. Id. at 2783.

117. Id. at 2778 (citing Wilson v. Garcia, 471 U.S. 261, 266-67 (1985); Auto Workers v. Hoosier Cardinal Corp., 383 U.S. 696, 704 (1966); Campbell v. Haverhill, 155 U.S. 610, 617 (1895)).

118. Id. (quoting Agency Holding Corp. v. Malley-Duff \& Assocs., Inc., 483 U.S. 143, 147 (1987)).

119. Id. (quoting DelCostello v. International Bhd. of Teamsters, 462 U.S. 151, 161 (1983)). 
omy. Second, a court should decide whether any uniform statute of limitations should be derived from state or federal law. Third, before borrowing from a federal source, the court should consider "such factors as commonality of purpose and similarity of elements." 120

Until Lampf, the Supreme Court had declined to articulate the limitations period applicable to claims under section $10(\mathrm{~b})$ and Rule $10 \mathrm{~b}-5 .^{121}$ The Supreme Court used Lampf as its vehicle to create a uniform federal statute of limitations for Rule $10 \mathrm{~b}-5$ actions. The Court had three potential sources for a new statute of limitations in the 1933 and 1934 Acts: section 16(b) of the 1934 Act, section 20A of that Act, and the one-year/ three-year period used by other sections of both acts. First, the Court rejected the two-year statute of repose for short-swing profits contained in section 16(b) of the 1934 Act. ${ }^{122}$ The Court reasoned that section 16(b) was not analogous because it required disgorgement of unlawful profits and had a different focus than section 10(b) and the other express causes of action. ${ }^{123}$

Second, the Court rejected the five-year statute of limitations from section $20 \mathrm{~A}$ of the Exchange Act. ${ }^{124}$ In response to growing concern over the insider trading scandals of the 1980s, Congress passed the Insider Trading and Securities Fraud Enforcement Act of 1988, which articulated a specific cause of action for insider trading and provided a five-year limitations period. The SEC had encouraged the Court to follow this most recent congressional statute of limitations, reasoning that this would provide private litigants more time to bring suit and consequently assist SEC enforcement efforts. ${ }^{125}$ The Court rejected section 20A's expanded five-year limitations period, reasoning that section $20 \mathrm{~A}$ focused on the specific problem of insider trading and that it was not intended "to extend that enhanced protection to other provisions of the 1934 Act." 126

Finally, the Court adopted the one-year/three-year formula found in the remaining express causes of action in the Securities Acts. Although sections 9(e) and 18(c) of the Exchange Act and section 13 of the Securities Act all contain a one-year/three-year statute of limitations, there are variations in the language. Section 9(e) of the Exchange Act provides that "[n]o action shall be maintained to enforce any liability created under this section, unless brought within one year after the discovery of the facts constituting the violation and within three years after

120. Id. at 2779.

121. See Ernst \& Ernst v. Hochfelder, 425 U.S. 185, 210 n.29 (1976).

122. 15 U.S.C. $\$ 78 \mathrm{p}(\mathrm{b})(1988)$.

123. Lampf, $111 \mathrm{~S}$. Ct. at 2780 n.5.

124. 15 U.S.C. $\S 78 \mathrm{t}-1(\mathrm{~b})(4)$ (1988).

125. For a discussion of the role of private suits in facilitating SEC enforcement, see infra notes 167-74 and accompanying text.

126. Lampf, 111 S. Ct. at 2781. 
such violation." 127 Section 18(c) reads similarly, substituting "cause of action" for "violation."128 Section 13 of the Securities Act has a similar bifurcated limitations period, but it is more complicated. The first half requires that actions brought to enforce any liability created under section 11 or 12(2) must be "brought within one year after the discovery of the untrue statement or the omission, or after such discovery should have been made by the exercise of reasonable diligence." 129 The second half of section 13 creates a further limit in the form of a statute of repose: "In no event shall any such action be brought to enforce a liability created under section [11] or [12(1)] more than three years after the security was bona fide offered to the public, or under section [12(2)] more than three years after the sale." 130

The Court's decision to adopt a one-year/three-year limitations period was largely based on its inference of legislative intent, i.e., what Congress would have done had it enacted a statute of limitations for Rule 10b-5. The Court reasoned that there was "no clearer indication of how Congress would have balanced the policy considerations implicit in any limitations provision than the balance struck by the same Congress in limiting similar and related protections."131 The Court further reasoned that sections 9 and 18 of the Exchange Act were analogous to section 10 (b) because they were all intended " 'to protect investors against manipulation of stock prices.' "132

Thus persuaded that the one-year/three-year formula best reflected congressional intent, the Court explicitly adopted the specific language of section 9(e). ${ }^{133}$ But it did so in a footnote, never bothering to explain or justify its choice, glibly holding that "[t]o the extent that these distinctions [among "the various 1-and-3-year periods contained in the 1934 and 1933 Acts"] in the future might prove significant, we select as the governing standard for an action under $\S 10(\mathrm{~b})$ the language of $\S 9(\mathrm{e})$ of the 1934 Act."134 Because there is very little case law under section $9(\mathrm{e}),{ }^{135}$ and because the Court was more persuaded by the general need for a one-year/three-year formula than by the specific language of section

127. 15 U.S.C. $\$ 78 i(e)(1988)$.

128. "No action shall be maintained to enforce any liability created under this section unless brought within one year after the discovery of the facts constituting the cause of action and within three years after such cause of action accrued." Id. $\S 78 \mathrm{r}(\mathrm{c})$.

129. Id. $\S 77 \mathrm{~m}$.

130. Id. Section 11 creates a private right of action for false registration statements. $I d$. $\S 77 \mathrm{k}$. Section 12(1) gives investors a private right of action for uniawful sale of unregistered securities. $I d$. $\$ 71(1)$. Section 12(2) creates a private right of action for false or misleading statements in the sale of securities. Id. $\S 71(2)$.

131. Lampई, Pleva, Lipkind, Prupis \& Petigrow v. Gilbertson, 111 S. Ct. 2773, 2780 (1991).

132. Id. at 2781 (quoting Ernst \& Ernst v. Hochfelder, 425 U.S. 185, 195 (1976)).

133. Id. at 2782 n.9.

134. Id.

135. It is particuiarly ironic that the Court selected the language of section 9(e), given that noted commentators have observed that this section "has been a dead letter so far as producing 
9(e), this Comment will analyze the relevant case law under both section 9(e) of the Exchange Act and section 13 of the Securities Act. ${ }^{136}$

In adopting the one-year/three-year formula, the Court applied the new rule retroactively and dismissed the plaintiff's case because it had been filed after the new limitations period had expired. The Court expressly acknowledged that the one-year/three-year scheme would eliminate equitable tolling in securities fraud cases because it contains a statute of repose which is "fundamentally inconsistent" with tolling. ${ }^{137}$ However, the Supreme Court in Lampf did not explicitly address any of the ramifications of eliminating equitable tolling.

\section{The Aftermath of Lampf}

\section{The Congressional Response}

Lampf was controversial for three reasons. First, on average, it shortened the statute of limitations from that which had been applied using analogous state statutes of limitations. Second, the decision eliminated equitable tolling for securities fraud claims. Third, the decision was applied retroactively, causing dismissal of the case before the Court as well as all other pending Rule $10 \mathrm{~b}-5$ cases which did not meet the new Lampf statute of limitations. ${ }^{138}$

Congress responded to all three controversial aspects of the Lampf decision by proposing the Securities Investors Legal Rights Act of 1991. ${ }^{139}$ The House of Representatives version would have added a section 36 to the Securities Exchange Act of 1934. The proposed section read:

Except as otherwise provided in tlis Act, any private right of action arising from a violation of this Act shall be brought not later than the later of:

(1) 5 years after the date on which such violation occurred;

or

(2) 3 years after the date on which the violation was discovered or sliould liave been discovered through the exercise of rea-

recoveries is concerned." Louis LoSS, Fundamentals of SECuRITIES REgulation 920 (2d ed. 1988).

136. This is appropriate, in part, because post-Lampf courts have applied section 13 analysis, failing to discuss section $9(\mathrm{e})$ at all.

137. Lampf, $111 \mathrm{~S}$. Ct. at 2782.

138. On the same day that Lampf was decided, the Court decided a case which implied that Lampf would apply retroactively to all claims pending in federal court. Rejecting "selective prospectivity," two Justices in James B. Beam Distilling Co. v. Georgia expressed the view that "it is error to refuse to apply a rule of federal law retroactively after the case announcing the rule has already done so." 111 S. Ct. 2439, 2446 (1991) (Souter, J. \& Stevens, J.). Three other Justices stated their belief that all changes in the law made by federal judges must apply retroactively. Id. at 2450 51 (Blackmun, J., Marshall, J., \& Scalia, J., concurring).

139. H.R. 3185, 102d Cong., 1st Sess. (1991); S. 1533, 102d Cong., 1st Sess. (1991). 
sonable diligence. ${ }^{140}$

The Senate version, adopted by the Committee on Banking, Housing, and Urban Affairs as S. 1533, differed in substance from the House proposal only in that it allowed two years from constructive discovery instead of three. ${ }^{141}$ Subsequently, S. 1533 became an amendment to S. 543, the Comprehensive Deposit Insurance Reform and Taxpayer Protection Act of 1991. ${ }^{142}$

Both the House and Senate versions were noteworthy because they eliminated all statutes of repose. By providing that plaintiffs were bound by the later of the two limitations periods, the second limitation based on unqualified equitable tolling became controlling. The five-year limit could be easily circumvented by claiming the fraud had been concealed. Thus, the preliminary congressional agreement boded significant change.

Unfortunately, Congress' ultimate resolution of the matter was considerably less dramatic, if not anticlimactic. Accounting firms and the securities industry lobbied hard to keep Congress from overturming Lampf. ${ }^{143}$ The heated debate in the Senate quickly became moot because Congress wanted to expedite passage of the main bill, S. 543, necessary to replenish the Federal Deposit Insurance Fund. ${ }^{144}$ The watered-down S. 543 amendment ultimately dealt only with the retroactive application of the one-year/three-year formula, not with the other two problems raised by Lampf. It did so by adding to the Exchange Act a new section 27A, which resurrected those Rule $10 \mathrm{~b}-5$ suits rendered stale by Lampf. ${ }^{145}$ Congress did not change the actual limitations period or adopt any form of equitable tolling for those cases filed after June 19, 1991.

140. H.R. 3185, § 2(a) (emphasis added).

141. S. $1533, \S 1(\mathrm{a})$.

142. 102d Cong., Ist Sess. (1991). The bill, as amended, was eventually enacted as the Federal Deposit Insurance Corporation Act of 1991, Pub. L. No. 102-242, §476, 105 Stat. 2236, 2387 (codified at 12 U.S.C. $\$ 1811$ (Supp. III 1992); see also H.R. REP. No. 1096, 102d Cong., 2d Sess. (1992) (describing how part of H.R. 3185 was moved into S. 543).

143. Lyman Johnson, Securities Fraud and the Mirage of Repose, 1992 WIS. L. REV. 607, 610 n.6.

144. Verges, supra note 108 , at 36.

145. The new section 27A of the Securities Exchange Act of 1934 reads:

SPECIAL PROVISION RELATING TO STATUTE OF LIMITATIONS ON PRIVATE CAUSES OF ACTION

(a) EFFECT ON PENDING CAUSES OF ACTION-The limitation period for any private civil action implied under section $78 \mathrm{j}(\mathrm{b})$ of this title that was commenced on or before June 19, 1991, shall be the limitation period provided by the laws applicable in the jurisdiction, including principles of retroactivity, as such laws existed on June 19, 1991.

(b) EFFECT ON DISMISSED CAUSES OF ACTION-Any private civil action implied under Section 78j(b) of this title that was commenced on or before June 19, 1991-

(1) which was dismissed as time barred subsequent to June 19, 1991, and

(2) which would have been timely filed under the limitation period provided by the laws applicable in the jurisdiction, including principles of retroactivity, as such laws existed on June 19,1991 , shall be reinstated on motion by the plaintiff not later than 60 days after December 19, 1991.

15 U.S.C. \& 78aa-1 (Supp. III 1992). 


\section{The Lower Courts' Application of Lampf}

The Supreme Court in Lampf clearly precluded the application of equitable tolling to Rule $10 \mathrm{~b}-5$ cases. ${ }^{146}$ In an effort to be more precise, some courts have reasoned that the new bifurcated one-year/three-year formulation for Rule $10 \mathrm{~b}-5$ cases does permit equitable tolling, but only for a maximum of three years. ${ }^{147}$ These courts have therefore applied equitable tolling to the one-year limit. Although one district court had applied the equitable tolling doctrine to section 13's outer three-year limitation, ${ }^{148}$ this case was distinguished by subsequent courts for its "extraordinary facts" 149 and was eventually reversed on appeal. The consensus of circuit opinions and clear language of the Lampf opinion precludes equitable tolling in Rule $10 \mathrm{~b}-5$ cases. ${ }^{150}$

The Lampf Court did not explicitly address whether or not equitable estoppel was available under the one-year/three-year formula. ${ }^{151}$ Lampf borrowed section 9's limitation period, concerning which there is not much case law. Thus, we must look to the courts' treatment of claims brought under section 13 of the Securities Act to shed light on whether equitable estoppel survived Lampf. Although some courts have held that defendants may be equitably estopped from asserting the statute of limitations defense under section $13,{ }^{152}$ the apparent consensus of the lower courts is that they may not. ${ }^{153}$

146. See supra note 137 and accompanying text.

147. See, e.g., Farley v. Baird, Patrick \& Co., 750 F. Supp. 1209, 1214 (S.D.N.Y. 1990); Dymm v. Cahill, 730 F. Supp. 1245, 1255 (S.D.N.Y. 1990); see also In re National Mortgage Equity Corp. Mortgage Pool Certificates Sec. Litig., 636 F. Supp. 1138, 1167 (C.D. Cal. 1986) (adopting equitable tolling for the one-year period of $\S 13$ of the Securities Act).

148. In re Home-Stake Prod. Co. Sec. Litig., 76 F.R.D. 337, 344-45 (N.D. Okla. 1975), rev'd sub nom. Anixter v. Home-Stake Prod. Co., 939 F.2d 1420, modified on other grounds, 947 F.2d 897 (10th Cir. 1991), yacated on other grounds, 112 S. Ct. 1658 (1992).

149. Farley, 750 F. Supp. at 1219; Zola v. Gordon, 685 F. Supp. 354, 362 (S.D.N.Y. 1988).

150. See, e.g., SEC v. Seaboard Corp., 677 F.2d 1301, 1308 (9th Cir. 1982); Summer v. Land \& Leisure, Inc., 664 F.2d 965, 968 (5th Cir. 1981), cert. denied, 458 U.S. 1106 (1982); Armbrister v. Roland Int'l Corp., 667 F. Supp. 802, 823 (M.D. Fla. 1987); Benoay v. Decker, 517 F. Supp. 490, 496 (E.D. Mich. 1981), aff'd, 735 F.2d 1363 (6th Cir. 1984). However, at least one commentator has argued that Lampf did not eliminate all equitable tolling. See infra notes 158-65 and accompanying text.

151. Borden, Inc. v. Spoor Behrins Campbell \& Young, Inc., 778 F. Supp. 695, 698 (S.D.N.Y. 1991).

152. Dahl v. Gardner, 583 F. Supp. 1262, 1265 (C.D. Utah 1984) (citing Aldrich v. McCulloch Properties, Inc., 627 F.2d 1036 (10th Cir. 1980), which analyzed similar language under the Interstate Land Sales Full Disclosurc Act). By way of analogy, the Interstate Land Sales Full Disclosure Act (ILSFDA), 15 U.S.C. $\$ \S 1701-1717$ (1988), explicitly provides that an action shall in no event be brought more than three years after the cause of action has accrued, id. $\S 1711$. Cases interpreting the ILSFDA have held that even though equitable tolling cannot be used to extend the outer limit, equitable estoppel can. See Cook v. Deltona Corp., 753 F.2d 1552, 1562-63 (11th Cir. 1985); Aldrich v. McCulloch Properties, Inc., 627 F.2d 1036, 1043 n.7 (10th Cir. 1980); Bomba v. W.L. Belvidere, Inc., 579 F.2d 1067, 1070-71 (7th Cir. 1978).

153. This apparent consensus is consistent with the circuit courts' tendency to disallow equitable tolling in Rule 10b-5 actions. See cases cited supra note 150. 
Between the Data Access and Lampf decisions, those courts following the Third Circuit's lead had held that section 13's one-year/threeyear formula meant that equitable estoppel was no longer available for Rule 10b-5 claims. For example, the Seventh Circuit, following Data Access, held that neither equitable tolling nor estoppel could extend the three-year bar. ${ }^{154}$

Cases after $L a m p f$ have also held that equitable estoppel is not available for Rule 10b-5 claims. The Tenth Circuit explained that

the more accurate analysis [of section 13] excludes the application of [equitable estoppel] when the consequence operates to trump a clear outer limit intended by Congress. "Unless the 'in no event more than three' language cuts off claims of tolling and estoppel at three years, however, it serves no purpose at all-what other function could be served by such language in a statute that starts the time on discovery?" We therefore conclude that the doctrine of equitable estoppel is not available to avoid the statute of repose established by section $13 .{ }^{155}$

Similarly, the Southern District of New York noted "that the three-year period of repose acts as an absolute bar to plaintiff's Section 10(b) claims." 156 The clear consensus among the lower courts is that Lampf eliminated equitable estoppel for Rule 10b-5 cases, at least beyond the three-year absolute limit. ${ }^{157}$ Thus, in its quest for uniformity, Lampf eradicated both equitable doctrines, tolling and estoppel.

\section{One Novel Interpretation of Lampf}

At least one commentator, Professor. Lyman Johnson, has argued that Lampf has no meaningful effect and that the new three-year clock does not start to run until constructive notice because the Rule 10b-5 misconduct is ongoing until then. ${ }^{158}$ Citing Bailey, ${ }^{159}$ Johnson argues that in the nineteenth century there were two independent grounds for tolling a statute of limitations-the initial fraud itself, and subsequent

154. Short v. Belleville Shoe Mfg. Co., 908 F.2d 1385, 1391 (7th Cir. 1990) ("Unless the 'in no event more than three' language cuts off claims of tolling and estoppel at three years ... it serves no purpose at all . ..."), cert. denied, 111 S. Ct. 2887 (1991).

155. Anixter v. Home-Stake Prod. Co., 939 F.2d 1420, 1436 (quoting Short, 908 F.2d at 1391), modified on other grounds, 947 F.2d 897 (10th Cir. 1991), vacated on other grounds, 112 S. Ct. 1658 (1992). In addition, the Anixter court specifically noted that while Lampf did not acknowledge the elimination of equitable estoppel, as it did for equitable tolling, that elimination was a foregone conclusion. Id. at 1436 n.27 ("Although Lampf, Pleva did not address this issue, its holding the doctrine of equitable tolling inapplicable to the one-year/three-year limitary structure would necessarily foreclose application of equitable estoppel as well.").

156. Mekhjian v. Wollin, 782 F. Supp. 881,886 (S.D.N.Y. 1992) (emphasis added).

157. See also Borden, Inc. v. Spoor Behrins Campbell \& Young, Inc., 778 F. Supp. 695, 698-99 (S.D.N.Y. 1991) (following Anixter); Covell v. Photo Images, Inc., 774 F. Supp. 1321, 1325-26 (D. Kan. 1991) (same).

158. Johnson, supra note 143, at 664 .

159. Bailey v. Glover, 88 U.S. (21 Wall.) 342 (1874). 
fraudulent concealment of that fraud. Johnson explains that these two branches were conflated into the so-called "equitable tolling doctrine," a phrase of which he disapproves. ${ }^{160}$ Johnson believes that in eliminating "equitable tolling," the Court merely precluded the first basis for tolling, but that fraudulent concealment can still toll the statute of limitations for Rule 10b-5 cases. ${ }^{161}$

This argument has three flaws. First, it confuses the idea of tolling with the time when the statute of limitations starts running. Before Lampf, courts held that the violation occurred and the limitations period started running on the date when the fraudulent securities were sold. This period was tolled until actual or constructive notice of fraud, but this did not mean that the violation of Rule 10b-5 was continuing; it merely meant that the statute of limitations was not running because it had been tolled. The violation occurred at the time of sale; the limitations period started running later solely because of equitable doctrines. Without equitable toling, the three-year clock starts running on the date of sale. ${ }^{162}$

Second, the Supreme Court explicitly held in Lampf that equitable tolling is no longer available for Rule $10 \mathrm{~b}-5$ cases. ${ }^{163}$ Regardless of the historical underpinnings of the equitable tolling doctrine, the doctrine as it is currently understood and applied includes fraudulent concealment. Johnson himself admits that after Holmberg, this conflation was a fait accompli. ${ }^{164}$ Johnson is correct that the so-called "equitable tolling doctrine" contains two separate principles for tolling. However, when the Court eliminated the doctrine in its entirety, it abolished both branches.

Third, all of the circuits to adjudicate Rule 10b-5 cases since Lampf have precluded all tolling. ${ }^{165}$ This makes it clear that the current judiciary does not maintain the historical distinction between initial fraud and subsequent fraudulent concealment on which Johnson's argument relies. As Lampf is interpreted and applied by lower courts, it eliminates all forms of equitable tolling. Part III will argue that this purge is undesirable.

\section{III}

The CASE for Equitable Doctrines in

\section{RULE 10b-5 SUITS}

The securities laws represent an attempt to achieve many competing goals. For example, they balance the goals of full disclosure of informa-

160. Johnson, supra note 143 , at $641-42$.

161. Id. at 652 .

162. See Suslick v. Rothschild Sec. Corp., 741 F.2d 1000, 1005 (7th Cir. 1984).

163. Lampf, Pleva, Lipkind, Prupis \& Petigrow v. Gilbertson, 111 S. Ct. 2773, 2782 (1991).

164. Johnson, supra note 143 , at 649-50.

165. See supra notes $146-57$ and accompanying text. 
tion to investors with the problems of overloading investors with nonmaterial information and of imposing unreasonable burdens on corporations seeking to raise capital. Section $A$ of this Part will examine the purposes behind the securities fraud laws and discuss whether eliminating equitable doctrimes achieves these goals. Section B will examine the general purposes behind statutes of repose and discuss whether they apply in the context of securities fraud. Section $C$ will discuss why, even though a statute of repose may be appropriate for the express private causes of action under the 1933 and 1934 Acts, it promotes underdeterrence of fraud in Rule 10b-5 cases without avoiding any overdeterrence of beneficial behavior.

\section{A. The Purposes of Securities Laws}

The overriding purpose of securities regulation is to ensure the smooth operation of securities markets. Broadly speaking, this purpose is accomplished by ensuring full disclosure to investors ${ }^{166}$ and by preventing securities fraud and other unfair practices which destroy public confidence in the integrity of the securities markets.

This Section discusses three more specific goals of the securities laws, especially in the context of private enforcement. These can be divided into two major categories: preventing fraud from occurring at all and responding properly when fraud does occur. Deterrence prevents fraud and is thus the primary goal of Rule $10 \mathrm{~b}-5$ and other securities fraud laws. When deterrence fails, the focus shifts to compensating victims and disgorging ill-gotten gains from wrongdoers. The first goal is, of course, more important: when it is accomplished, secondary goals become moot. This Comment argues that all of these goals are best served by applying equitable doctrines to Rule $10 \mathrm{~b}-5$ cases.

Before discussing the specific goals of the securities laws, however, this Comment will argue that the evolution of more complex forms of securities fraud makes private suits increasingly necessary for effective enforcement of Rule 10b-5. Although the three-year statute of repose only applies to private claims, and the SEC may bring suit without time restrictions, private cases brought under Rule $10 \mathrm{~b}-5$ are increasingly necessary for the successful implementation of federal securities laws. In its amicus brief in Lampf, the SEC contended:

Rule $10 \mathrm{~b}-5$ is vastly more important in combatting fraud than are the express remedies provided in the 1933 and 1934 Acts. Borrowing the shorter limitations periods found in those Acts for Rule 10b-5 would impede enforcement of the Rule's require-

166. See Randall v. Loftsgaarden, 478 U.S. 647, 664 (1986) ("Congress intended . . . to ensure full disclosure of information material to investment decisions."); Ernst \& Ernst v. Hochfelder, 425 U.S. 185, 195 (1976) ("The Securities Act of 1933 was designed to provide investors with full disclosure of material information concerning public offerings of securities ...." (citation omitted)). 
ments, and would thereby impair the securities laws' function of protecting investors. ${ }^{167}$

The SEC went on to urge the Court to continue equitable tolling in Rule 10b-5 cases in order to facilitate private suits which assist in the enforcement of securities fraud laws. The Supreme Court has acknowledged that private cases under section 10(b) are "an essential tool for enforcement of the 1934 Act's requirements,"168 and has recognized "the congressional policy favoring private suits as an important mode of enforcing federal securities statutes."169

Private Rule 10b-5 suits are necessary for at least three reasons. First, SEC resources are limited. ${ }^{170}$ Furthermore, "the securities markets have grown dramatically in size and complexity, while Commission enforcement resources have declined."171 The Supreme Court has recognized the Securities and Exchange Commission's concern that it "does not have the resources to police the [securities] industry sufficiently."172 Second, private suits can be precursors to larger SEC actions. ${ }^{173}$ Finally, only private suits serve the goal of compensating victims of securities fraud. ${ }^{174}$

\section{Deterring Fraud}

Preventing fraud is a primary goal of federal securities regulation. ${ }^{175}$ Fraud decreases the public's confidence in the securities markets and inhibits the efficient raising of capital. This Section argues that by eliminating the equitable doctrines of tolling and estoppel, the Lampf decision thwarts efforts to deter securities fraud. This is true for four reasons. First, in theory, creating any new defenses will generally diminish deterrence. Second, in practice, the three-year time window without tolling is simply too short. Third, Lampf discourages investors from exercising

167. Brief for the Securities \& Exchange Commission as Amicus Curiae at 23, Lampf, Pleva, Lipkind, Prupis \& Petigrow v. Gilbertson, 111 S. Ct. 2773 (1991) (No. 90-333) [hereinafter SEC Lampf Amicus Brief].

168. Basic Inc. v. Levinson, 485 U.S. 224, 231 (1988); see also J.I. Case Co. v. Borak, 377 U.S. 426,432 (1964) (referring to private actions as "a most effective weapon in the enforcement" of federal securities laws and "a necessary supplement to Commission action").

169. Pinter v. Dahl, 486 U.S. 622, 633 (1988).

170. See, e.g., Woolf v. S.D. Cohn \& Co., 521 F.2d 225, 227 (5th Cir. 1975) ("The scarce enforcement resources of the S.E.C. are adequate only to police the most flagrant and widespread abuses in the private placement area.").

171. Bateman Eichler, Hill Richards, Inc. v. Berner, 472 U.S. 299, 315 (1985) (quoting H.R. REP. No. 355, 98th Cong., 1st Sess. 6 (1983)).

172. Id. (noting the SEC's concern that it cannot adequately police false tipping).

173. See Stephenson v. Paine Webber Jackson \& Curtis, Inc., 839 F.2d 1095, 1099 (5th Cir.) (private complaints help "to enable those with authority to control wrongdoing before additional investors are injured"), cert. denied, 488 U.S. 926 (1988).

174. See infra note 248 and accompanying text.

175. See Chiarella v. United States, 445 U.S. 222, 226 (1980) ("Section 10(b) was designed as a catchall clause to prevent fraudulent practices."). 
due diligence and discovering fraud. Finally, Lampf encourages fraudulent concealment by rewarding successful wrongdoers.

\section{a. Deterrence Theory}

People engage in white collar crime, including securities fraud, when the perceived benefits outweigh the perceived costs. ${ }^{176}$ The costs are a function of the cost of punishment (i.e. fines, imprisonment, and loss of reputation) multiplied by the probability of punishment. The probability of pumshment is in turn a function of the likelihood of detection multiplied by the probability of punishment given detection. Deterrence is enhanced by increasing either the probability of punishment (e.g. greater enforcement) or the cost of punishment (e.g. stiffer fines or jail sentences) or both. This Comment focuses on the first of these factors, probability of punishment.

Broadly speaking, the probability of punishment is a function of a two-step syllogism. First, the illegal activity must be detected. Second, once detected, the illegal activity must be punished. ${ }^{177}$ Eliminating equitable tolling weakens both prongs of the syllogism. First, it decreases the probability of detection by curbing the victims' incentives to exercise due diligence and increasing the wrongdoers' incentives to fraudulently conceal their crime. Second, it decreases the likelihood of punishment if wrongdoing is detected by providing a defense to those wrongdoers who fraudulently conceal their actions for three years or successfully convince their victims not to prosecute for three years.

Before discussing the specific reasons why the Lampf rule undermines deterrence of securities fraud, it should be noted that, in theory, creating new defenses to legal liability for any wrongful act always diminishes deterrence, since it decreases the likelihood that wrongdoers will be held accountable. For example, in Bateman Eichler, Hill Richards, Inc. v. Berner, ${ }^{178}$ the Supreme Court held that there should be no in pari delicto defense in securities fraud cases, in part because the extension of defenses diminishes deterrence. ${ }^{179}$ When new defenses are established, defendants are less likely to be held accountable even if they are brought into court, thus decreasing deterrence. Because plaintiffs are less likely to recover, they will be less likely to invest resources in investi-

176. This Comment explicitly assumes that all players rationally calculate costs and benefits, acting only when the benefits exceed the costs.

177. The amount of punishment must be high enough that when it is multiplied by the probability of punishment, the resulting penalty outweighs the perceived benefits of the activity for the wrongdoer. Deterrence is therefore maximized by increasing the probability of detection and by increasing the likelihood of punishment given detection.

178. 472 U.S. 299 (1985).

179. See id. at 307-08; see also Perma Life Mufflers, Inc. v. International Parts Corp., 392 U.S. 134,139 (1968) (precluding the defense of in pari delicto in antitrust cases, reasoning that antitrust laws "are best served by insuring that the private action will be an ever-present threat to deter anyone contemplating [illegal] business behavior"). 
gating fraud and initiating litigation in the first place. This too diminishes deterrence. ${ }^{180}$

\section{b. In Practice, an Absolute Three-Year Bar Is Too Harsh on Plaintiffs}

In addition to the general theory that creating defenses diminishes deterrence, in practice an absolute three-year window of opportunity to bring suit for securities fraud tends to be far too narrow. In general, "most corporate crimes seem highly concealable. This is so because, unlike victims of classically under-reported crimes (such as rape or child abuse), victims of many corporate crimes do not necessarily know of their injury." 181 Securities fraud is particularly hard to descry because "[v]iolations mvolving financial fraud ... often go undetected until the enterprise fails, an event that may occur years after the violation." 182 The Securities and Exchange Commission noted that "even the SEC with all its mvestigative resources and statutory powers, including compulsory investigative processes, does not complete its investigations, on average, in less than 2.25 years." ${ }^{183}$ Note that this is 2.25 years from the start of the investigation, not the violation. The violation occurs on the date the security is sold. ${ }^{184}$ Thus, it is unlikely that even the SEC could initiate half of its current suits within a three-year threshold. For the same reasons, a three-year limit means that most private Rule 10b-5 claims will never be adjudicated on their merits. ${ }^{185}$ This seriously sabotages meaningful deterrence.

This Comment will illustrate the inadequacy of a three-year limit by examining five different types of conduct which are actionable under Rule 10b-5: Ponzi schemes, fraudulent municipal bonds, securities in natural resources, investments in technical fields, and limited partnership tax shelters. ${ }^{186}$ But even articulating and discussing specific forms of

180. Of course, this does not mean that all limitations periods should be eliminated. The deterrence interest can be outweighed at some point by other interests served by statutes of limitations. However, this Comment develops specific reasons why statutes of repose reduce the deterrent value of securities laws without avoiding any overdeterrence of beneficial conduct.

181. John C. Coffee, Jr., "No Soul to Damn: No Body to Kick": An Unscandalized Inquiry into the Problem of Corporate Punishment, 79 MiCH. L. REV. 386, 390 (1981).

182. SEC Lampf Amicus Brief, supra note 167, at 24.

183. Id. at 24 n.37.

184. Suslick v. Rothschild Sec. Corp., 741 F.2d 1000, 1005 (7th Cir. 1984) ("It is settled that a cause of action under either the Securities Act of 1933 or the Securities Exchange Act of 1934 arises on the date the sale of the instrument is completed.").

185. Although it could be argued that under Lampf investors will simply perform their due diligence within the first three years after the sale of securities, this Comment takes the position that such a response is both unlikely and insufficient. See infra text following note 235.

186. Of course, many types of fraud can be easily discovered within a one-year, not to mention a three-year, window. For example, fraud of the varicty found in Basic Inc. v. Levinson, 485 U.S. 224 (1988), is readily apparent. In Basic, a company denied that merger negotiations were occurring and then several days later announced that a merger deal had been struck. Investors who relied on the false information and traded to their detriment can be expected to realize immediately that they have a cause of action under Rule $10 \mathrm{~b}-5$ and that they should bring suit without delay. In general, false 
securities fraud downplays the investors' predicament, because such discussion suggests that securities fraud involves a limited number of recognized, common species of inisconduct. On the contrary, securities fraud is often difficult to detect because investors do not know what they are looking for. Indeed, section 10(b) was designed as a catch-all antifraud provision precisely in order to handle unforeseen and "cunning" varieties of securities fraud that could not be anticipated. ${ }^{187}$ The most invidious forms of securities fraud are the ones yet to be named and studied. As the Second Circuit explamed: "[Section] 10(b) and Rule 10b-5 prohibit all fraudulent schemes in connection with the purchase or sale of securities, whether the artifices employed involve a garden type variety of fraud, or present a urique form of deception. Novel or atypical methods should not provide immunity from the securities laws."188 With this caveat, let us examine five examples that illustrate the inappropriateness of a three-year statute of repose for Rule 10b-5 actions.

\section{i. Ponzi Schemes}

The Ponzi scheme is a fraud where the wrongdoer establishes a phony business and funnels the funds of new investors to previous investors in order to create the illusion of profits. A successful Ponzi scheme can stand for several years before there is any indication that the underlying business is bogus and other people's money is merely being recycled. ${ }^{189}$ Under a three-year statute of repose, victims can be precluded from compensation if they do not uncover the fraud within three years from purchase. But ascertaining that the business underlying a Ponzi scheme is phony can be an arduous task. It is particularly difficult, if not impossible, to detect when the wrongdoer uses a shell business which the investor can actually see. ${ }^{190}$

Knowing that there is an absolute three-year bar provides the Ponzi artist with a safe harbor that she can use when planning her fraud. The Ponzi prey may be unable to recover under two scenarios. First, the wrongdoer can decide to stop recruiting new investors at a certain point. For the next three years, the wrongdoer need only pay interest on the initial investment. At the end of that period, the wrongdoer stops payments and retains the remaining principal. None of the victims can bring

statements about upcoming events-such as mergers-are usually exposed quickly. Thus, Lampf does not completely emasculate Rule $10 \mathrm{~b}-5$, but it still keeps many plaintiffs from bringing suit in a wide range of cases.

187. Ernst \& Ernst v. Hochfelder, 425 U.S. 185, 203 (1976).

188. A.T. Brod \& Co. v. Perlow, 375 F.2d 393, 397 (2d Cir. 1967).

189. See, e.g., In re Johnson, 960 F.2d 396, 398 (4th Cir. 1992) (describing a Ponzi scheme which ran for six years).

190. See, e.g., Daniel Akst, How Barry Minkow Fooled the Auditors, Forbes, Oct. 2, 1989, at 126 (describing how a Ponzi scheme fooled auditors by staging believable front operations). 
suit, because they all purchased their securities more than three years before the collapse.

Second, the investors at the top of the pyramid in well-sustained schemes are out of luck no matter when the pyramid stops growing or collapses. If a new layer of investors is added every year, each year another layer of victims at the top of the pyramid is precluded from bringing suit. For example, when a Ponzi scheme enters its fourth year, anyone who invested during the first year is precluded from bringing suit under Rule 10b-5. In the fifth year, all those investors who joined in the second year of the pyramid are similarly precluded from bringing suit. So even if the Ponzi artist is caught, a new class of victims is denied compensation with each passing year.

\section{ii. Fraudulent Municipal Bonds}

Along with stocks, bonds are the most familiar type of "security." Bonds are a predictable mechanism for corporations and governments to raise long-term capital. For convenience, and because they receive less regulation than other bonds, this Section will focus on municipal bonds. ${ }^{191}$ With a current face value of approximately $\$ 830$ billion, municipal bonds are a significant component of American capital markets. ${ }^{192}$ Their face value is three times greater than that of all corporate bonds in the market. ${ }^{193}$ The current default rate for municipal bonds is one billion dollars per year. ${ }^{194}$ The potential for fraud is therefore significant.

Although municipal bonds are generally safer than corporate bonds, they are not immune from Rule 10b-5 violations. ${ }^{195}$ Investors have made claims against both the issuers and underwriters of municipal bonds ${ }^{196}$ and the municipality itself. ${ }^{197}$ Unscrupulous promoters may convince

191. Although much of the specific discussion focuses on municipal bonds, the principles and problems articulated generally apply to corporate bonds as well.

192. Brief of Bond Investors Ass'n as Amicus Curiae at 4, Lampf, Pleva, Lipkind, Prupis \& Petigrow v. Gilbertson, 111 S. Ct. 2773 (1991) (No. 90-333) [hereinafter BIA Lampf Amicus Brief] (citing Christopher Farrell, Once Upon a Time, a Muni Was a Muni Was a Muni . .., Bus. WK., Dec. 31, 1990, at 121).

193. Id. at 4-5 (citing Jonathan R. Laing, The New Junk? Risks Are Rising in the Vast Municipal Bond Market, BARRoN's, Oct. 29, 1990, at 10).

194. Id. at 5.

195. See, e.g., Freeman v. Laventhol \& Horwath, 915 F.2d 193, 195 (6th Cir. 1990) (discussing a Rule 10b-5 "class action aris[ing] from the sale of tax-exempt municipal bonds to finance the construction of a retirement center"); Bradford Sec. Processing Servs. v. County Fed. Sav. \& Loan Ass'n, 474 F. Supp. 957, 958-60 (S.D.N.Y. 1979) (describing Rule 10b-5 suit against S\&L for selling municipal bonds, known as Industrial Development Revenue Bonds (IDRs), where the underlying values of the projects to be financed were fraudulently inflated).

196. See, e.g., Swink \& Co. v. Hereth, 784 F.2d 866 (8th Cir. 1986) (involving suit against underwriters for alleged violation of Rule $10 \mathrm{~b}-5$ in connection with sale of municipal bonds).

197. See, e.g., Brown v. City of Covington, 805 F.2d 1266, 1267 (6th Cir. 1986) (explaining how promoters developed municipal bond scheme to profit from health care center for which there was no established need). 
municipalities to sponsor a bond issue from which the promoters divert funds to improper uses. ${ }^{198}$ For example, in T.J. Raney \& Sons, Inc. $v$. Fort Cobb, Oklahoma Irrigation Fuel Authority, ${ }^{199}$ the project's sponsors allegedly commingled the municipal bond proceeds with other funds and diverted the bond proceeds. The municipal bonds defaulted, leaving the investors high and dry. ${ }^{200}$ While creating dummy projects and diverting funds can be a complicated affair, securities fraud in municipal bonds can also be relatively simple. For example, the Rule $10 \mathrm{~b}-5$ violation can be the false assertion that bonds are municipal bonds backed by a city's resources when in fact they are not. ${ }^{201}$ Wrongdoers may make such a claim because municipal bonds are generally considered a safe investment; this may lull victims into a false sense of security.

Fraudulent bonds are the clearest example of securities fraud which is undetectable within a three-year statute of repose, as long as their maturity date is greater than three years. Since the violation occurs at the time of sale, victims have three years from the date of the sale to bring suit. But how could purchasers have any indication that the security is fraudulent until return of principal is not made, ${ }^{202}$ which could easily be more than three years after the sale? After selling the worthless paper, the wrongdoer need not engage in subsequent affirmative misconduct over the next three years. She simply makes the coupon interest payments, if any, for three years and then defaults after the statute of repose has expired. A fraudulent bond with a five-year maturity could represent a form of self-concealing fraud, what Bailey defined as "committing a fraud in a manner that it concealed itself until such time as the party committing the fraud could plead the statute of limitations."203 The passage of time renders such frauds immune from private Rule $10 \mathrm{~b}$ 5 actions without giving investors any storm warning-indeed, without alerting them that there is a cloud in the sky.

Problems of detection are magnified by the fact that municipal bonds are exempt from the registration requirements of the Securities Act, ${ }^{204}$ the periodic reporting requirements of the Exchange Act, ${ }^{205}$ the

198. See, e.g., Abell v. Potomac Ins. Co., 858 F.2d 1104, 1109-10 (5th Cir. 1988) (concerning a wrongdoer who convinced the city to back a $\$ 12.85$ million municipal bond issue to finance a fraudulent home for the mentally and emotionally disturbed), vacated sub nom. Fryar v. Abell, 492 U.S. 914, and cert. denied, 492 U.S. 918 (1989).

199. 717 F.2d 1330, 1331 (10th Cir. 1983), cert. denied, 465 U.S. 1026 (1984).

200. Id. at 1331-32.

201. See, e.g., Ross v. Bank South, N.A., 837 F.2d 980, 997 (11th Cir.), vacated, 848 F.2d 1132 (11th Cir. 1988), and cert. denied, 495 U.S. 905 (1990).

202. See Loveridge v. Dreagoux, 678 F.2d 870, 875 (10th Cir. 1982) (holding that investors did not have notice of an alleged fraud until the maturity date of their debt securities had passed without repayment of principal).

203. Bailey v. Glover, 88 U.S. (21 Wall.) 342, 349 (1874).

204. 15 U.S.C. $\$ 77 \mathrm{c}(\mathrm{a})(2)(1988)$ (Section 3(a)(2) of the 1933 Act).

205. 15 U.S.C. $\S \S 78 c(a)(12), 781(a), 78 \mathrm{~m}(\mathrm{a}), 78 \mathrm{p}(\mathrm{a})$ (1988) (Sections 3(a)(12), 12(a), 13(a), 14(a) and $16(\mathrm{a})$ of the 1934 Act). 
Trust Indenture Act of $1939,{ }^{206}$ and most registration requirements under state blue sky laws. ${ }^{207}$ Bondholders receive no consistent flow of information. Whatever information is sent may not be received by the beneficial owners of the securities because many bonds are held in "street name."208 Because of this, bondholders are unlikely to have any idea that there may be problems until a coupon interest payment is missed. ${ }^{209}$ This problem is compounded because bond trustees maintain reserve funds, ${ }^{210}$ and municipal bond trustees often do not report defaults. ${ }^{211}$

A three-year time window is empirically too short to combat fraud in the sale of municipal bonds. Analyzing data from the 1980s, the Bond Investors Association noted in its Lampf amicus brief that the average length of time between the issuance of municipal bonds and default in repayment was approximately 4.5 years. $^{212}$ Thus, in most cases, the first storm warning will not sound until after private investors' ability to bring suit under Rule 10b-5 has expired. Lampf removes the teeth from Rule $10 \mathrm{~b}-5$ in these cases, thwarting the purposes behind the Rule. As with Ponzi schemes, the three-year statute of repose provides an effective tool for unscrupulous promoters to structure their fraud in a way that minimizes their potential liability. For example, wrongdoers are likely to focus on bonds with maturities over three years. Having sold bonds for projects which they have no intention of fully flnancing, they can make monthly coupon interest payments and develop cover stories to explain the lack of physical constructing, knowing that such fraudulent concealment will not toll the statute of limitations for Rule 10b-5 claims.

In addition to these considerations of fairness, deterrence, and compensation, Lampf's insulation of long-term bonds from Rule 10b-5 liability could have dire consequences for capital markets. If such bonds fall outside the protection of Rule $10 \mathrm{~b}-5$, they become relatively less attractive investments. The net effect may be to decrease the appeal of longterm capital markets. Even in a best-case scenario, this presents a classic market for lemons. Since no investor can be certain which long-term investments are safe and which will turn out to be fraudulent, all businesses must pay an interest premium to compensate for the additional risk of long-term investment. This additional interest premium could hurt financially strapped municipalities and startup companies. In a

206. 15 U.S.C. $\$ 77 d d d(a)(4)(A)$ (1988 \& Supp. III 1992) (Section 304(a)(4)(A) of the 1939 Trust Indenture Act).

207. See, e.g., UNIFORM SeCURITIES ACT $\S$ 402(a)(1), 7B U.L.A. 509 (1958) (superseded 1985).

208. BIA Lampf Amicus Brief, supra note 192, at 8 n.22.

209. Id. at 7.

210. Id.

211. Michael Fritz, X-Rated Bonds, Forbes, Mar. 21, 1988, at 167.

212. BIA Lampf Amicus Brief, supra note 192, at 7; see also SEC Staff Report on Transactions in the Marine Protein Corp. Industrial Development Revenue Bonds, [1979 Transfer Binder] Fed. Sec. L. Rep. (CCH) If 82,049, at 81,682 (Apr. 11, 1979) (describing bond default four years after issuance). 
worst-case scenario, wary investors may simply cease purchasing intermediate- and long-term bonds which mature after three years, because there is a disproportionate risk of nonremediable fraud. If so, this could have a disastrous impact on the ability of both municipalities and businesses to raise capital.

\section{iii. Securities in Underground Natural Resources}

Sales of securities often involve investment in oil wells and mineral deposits. ${ }^{213}$ Investors in these kinds of securities are particularly vulnerable because they must rely on techmical information provided by others. Rule 10b-5 claims typically arise when the seller falsifies data regarding the underlying asset. For exainple, in Freschi v. Grand Coal Venture, ${ }^{214}$ the plaintiff invested in fraudulent coal leases. In their offering memorandum, the defendants incorporated a report from "a self-styled 'geologist' without formal training in geology ... stating that there was a strong likelihood that the leased lands contained large coal reserves."215 The plaintiff in Freschi exemplifies the inherent vulnerability of natural resource investors because he investigated the deal diligently, consulting "with his accountant, his attorney, ... a coal mining executive, an attorney specializing in coal leases, and a geologist, who accompanied Freschi to a meeting with [the defendants' 'geologist']."216 Nothing in this extensive investigation indicated fraud. For over three years, Freschi waited for some return on his investment and received nothing but assurances of forthcoming profits. Freschi ultimately brought suit under Rule 10b-5 four years after he purchased the securities. The jury returned a verdict against all of the defendants involved in the fraudulent coal leases. If the Lampf rule had been in place, Freschi would have been thrown out of court before he had a chance to present his proof of fraud.

Freschi illustrates several points. A three-year statute of repose could be impractical for these securities, because it is difficult for investors to verify the existence of the underlying asset. Investors cannot observe oil wells and mineral deposits with their own eyes. More often than not, they must rely on the seller's truthfulness. Geological reports may be doctored or fabricated. ${ }^{217}$ Not only would it be difficult for inves-

213. See, e.g., Donohoe v. Consolidated Operating \& Prod. Corp., 982 F.2d 1130 (7th Cir. 1992) (oil drilling); SEC v. Rogers, 790 F.2d 1450 (9th Cir. 1986) (gold mines); Freschi v. Grand Coal Venture, 767 F.2d 1041 (2d Cir. 1985) (coal mines), vacated, 478 U.S. 1015 (1986); SEC v. Texas Gulf Sulphur Co., 401 F.2d 833 (2d Cir. 1968) (copper, zinc, and silver mines), cert. denied, 394 U.S. 976 (1969); Griffin v. McNiff, 744 F. Supp. 1237 (S.D.N.Y. 1990) (oil and gas limited partnerships), aff'd, 996 F.2d 303 (2d Cir. 1993).

214. 767 F.2d 1041 (2d Cir. 1985).

215. Id. at 1044 .

216. Id. at 1045 .

217. See, e.g., Shumate v. McNiff, [1990-1991 Transfer Binder] Fed. Sec. L. Rep. (CCH) I 95,916, at 99,541 (S.D.N.Y. 1991) (describing how Price Waterhouse pulled out of offering for securities in oil and gas drilling enterprises in part because it believed that the geology reports were 
tors to detect the asset, it may be equally difficult to detect fraud because not all potential wells and deposits will contain financially significant amounts of the relevant natural resource. These investments have inherent risks, and perfectly legitimate securities often will not pay off. Therefore, even if a potential oil or mineral field is a bust, it might activate a duty of inquiry, yet not be dispositive of fraud. Of course, this assumes the bad news is released within three years of the sale. After Lampf, clever wrongdoers would simply delay the news of the ultimate failure of the project for three years from the date of sale of the security. This would create an absolute defense against private suits. Furthermore, investors would have little incentive to retrace their steps and investigate the prospectus or the data that induced them to purchase their now-worthless securities because even if fraud had occurred, they could not bring suit for compensation.

One simplistic response to this dilemma might be to require greater diligence by investors. After all, if these types of securities involve a greater risk of fraud, then investors considering buying them should be more diligent prior to their purchase. While each investor could theoretically hire her own geologist to evaluate the data or the field independently, this is impractical for several reasons. First, with up to hundreds of buyers and potential buyers for any given security, it is inefficient for each investor independently to investigate. Second, it may be difficult for investors to obtain impartial geologists. Also, many investors believe that they have received an independent, impartial geologist's report. That is part of the fraud. Finally, at a certain point, all investors must rely on other people's data, scientific evaluations, and statements of facts. This may be because the other person is their fiduciary, because there is no reason to believe the information is false, or because there is no feasible alternative source of information. Whatever the reason, this reliance is an element of any Rule 10b-5 claim and should not be used to condemn investors who do not receive outside confirmation. After all, the securities laws were designed to eliminate the philosophy of caveat emptor and place an affirmative burden on sellers (and buyers) to fully and truthfully disclose material facts. ${ }^{218}$

\section{iv. Securities Involving Technical Data}

Many securities rely heavily on technical data. For example, the value of securities for pharmaceutical companies and high-tech industries can depend on the accuracy of technical data. When there is fraud in the

forged); Griffin, 744 F. Supp. at 1249 (same); Donohoe v. Consolidated Operating \& Prod. Corp., 736 F. Supp. 845, 871 (N.D. Ill. 1990) (involving allegedly misleading geologist's report in oil and gas limited partnerships), aff'd in part, vacated in part, and remanded, 982 F.2d 1130 (7th Cir. 1992).

218. SEC v. Capital Gains Research Bureau, Inc., 375 U.S. 180, 186 (1963). 
underlying data, the securities fraud will be difficult to detect. A threeyear statute of repose exacerbates this problem. The detection problems may be illustrated by two examples: drug data and patent applications.

Some securities are sold to finance the development of new pharmaceuticals. However, the average investor cannot understand sophisticated drug data and analyses. If the underlying drug data are fraudulent, investors will not be able to discover fraud until the crime is exposed by outside enforcement mechanisms. Indeed, sometimes even the federal regulators are deceived. For example, in Masnik v. Bolar Pharmaceutical Co., ${ }^{219}$ the defendant drug companies allegedly submitted false statements (concerning bioequivalency, a necessary condition for government approval of generic drugs) and test data to the Food and Drug Administration in order to get approval for a generic drug. The plaintiffs in this case were stockholders in the rival pharmaceutical company which made the name-brand drug targeted by the generic drug. The value of plaintiffs' stock declined as a result of the defendants' fraud and subsequent drug approval. The actual shareholders of the defendant drug companies, who financed the generic drug starting in the late 1980s, could not bring suit at that point because they had bought into the company, relying on the falsified drug data, more than three years before the fraud was exposed. The relevant authorities did not alert the shareholders in time; now, through no fault of their own, the injured shareholders cannot seek compensation under Rule 10b-5.

Other securities that depend on technical data are those issued by companies that rely on patent applications. Patent applications can be critical assets of companies whose securities are being sold. ${ }^{220}$ Indeed, in some cases, a patent application is a company's sole asset. ${ }^{221}$ The information in the patent application strongly influences the value of the corporation's securities. Falsifying the technical data in the patent application is an easy way to inflate the price of the firm's securities fraudulently. If there is fraud in the patent application, the investor should have recourse under Rule 10b-5. If that fraud is not exposed for three years, investors cannot bring suit. But it can take several years to process a patent application and uncover the fraud. Like all registered securities, securities in these types of companies are often accompanied by prospectuses which explain in general terms the risks of investing in technical areas. ${ }^{222}$ But such generic warnings do not reveal the risk that

219. No. 90-4086, 1991 U.S. Dist. LEXIS 10138 (E.D. Pa. July 18, 1991).

220. See, e.g., SEC v. North Am. Research \& Dev. Corp., 375 F. Supp. 465, $470-71$ (S.D.N.Y. 1974) (promoting stock sale with patent application for method of producing "pollution-free coke"), aff'd, 511 F.2d 1217 (2d Cir.), and cert. denied, 423 U.S. 830 (1975).

221. See, e.g., Reube v. Pharmacodynamics, Inc., 348 F. Supp. 900,903 n.7 (E.D. Pa. 1972).

222. See Pommer v. Medtest Corp., 961 F.2d 620, 624-25 (7th Cir. 1992) ("Such generic warnings do not enlighten investors about the status of patent applications, negotiations to sell the business, and the like...."). 
the patent application may have an inflated value, may be based on false data, or may be subject to preemption. Investors often will not have access to the raw data, let alone the ability to verify its accuracy. The prudent investor, relying on technical data and analyses provided by the company, may be defrauded. There is little the investor can do to expedite the discovery of fraud, and yet the victims of the securities fraud will be denied compensation if they do not discover the fraud in three years.

\section{v. Limited Partnership Tax Shelters}

Securities are often sold as investments in limited partnerships specifically designed for their tax benefits. Limited partnerships are often the subject of Rule 10b-5 litigation. Indeed, the securities at issue in Lampf were limited partnerships for purchasing and leasing computer equipment and software. ${ }^{223}$ By depreciating certain assets for tax purposes, tax shelters are designed to create a loss "on paper." Investors in tax shelters thus anticipate taking certain losses. Investors witness depreciation and use it as a tax write-off. They see nothing unexpected. Even a stream of losses would not necessarily raise eyebrows, especially if the investors are taking their tax deductions as planned.

The three-year statute of repose can facilitate fraud in tax shelters because sellers can lie about both the underlying asset and the investors' ability to claim certain losses as tax deductions. The fraud often lies in the fact that the losses are not really tax-deductible to the investor. There is no easy way for investors to determine whether the IRS will eventually disallow the deductions, especially if accountants are involved in the fraud and the investors have been deducting their losses for a while with apparent success.

- Victims may be unaware of a tax-shelter fraud until the Internal Revenue Service notifies them. ${ }^{224}$ Indeed, the plaintiffs in Lampf did not investigate the failure of their investments until five to seven years after their initial investments because that is when the IRS began disallowing their tax benefits. In short, the wrongdoer can structure the fraud so that it is not subject to private Rule $10 \mathrm{~b}-5$ actions. For example, the security could start generating losses only three years after the sale, so that any announcement of an IRS investigation would take place after the statute of repose had expired.

In limited partnership cases, Rule $10 \mathrm{~b}-5$ represents the best, if not only, hope of controlling wrongdoers. Because many limited partner-

223. Lampf, Pleva, Lipkind, Prupis \& Petigrow v. Gilbertson, 111 S. Ct. 2773, 2776 (1991).

224. The pain of being informed by the IRS of the underlying fraud after three years can add significant insult to injury because not only do victims find that they possess worthless securities, but they are now liable for past taxes and possible penalties. See Freschi v. Grand Coal Venture, 767 F.2d 1041, 1045 (2d Cir. 1985), vacated, 478 U.S. 1015 (1986); Griffin v. McNif, 744 F. Supp. 1237, 1242-43 (S.D.N.Y. 1990), aff'd, 996 F.2d 303 (2d Cir. 1993). 
ships are private placements under section 4(2) of the 1933 Act, they are often unregistered. ${ }^{225}$ Limited partnerships receive little SEC oversight, and there is scant publicly available information. Although limited partners have the right to demand access to records, ${ }^{226}$ if the initial records are fraudulent or the underlying securities are not tax deductible, there is little hope that a limited partner will discover the fraud without outside assistance. Limited partners must depend on the accuracy of the information they receive from the general partners who are the potential wrongdoers. Thus, limited partnerships present another situation in which Lampf may be used offensively to assist wrongdoers in structuring their fraud so as to limit their exposure to legal sanctions.

\section{c. Eliminating Equitable Tolling Decreases Incentives for Plaintiffs to Exercise Due Diligence}

Investors' due diligence serves several purposes. First, it stabilizes securities markets by increasing the probability that fraud will be detected. The Fifth Circuit has correctly observed that "standards relating to a plaintiff's conduct encourage an investor to complain promptly about violations of his or her rights and, in so doing, to enable those with authority to control wrongdoing before additional investors are injured. The SEC has from its inception encouraged diligence in stock transactions."227 In an earlier case, the Fifth Circuit succinctly noted that "by requiring plaintiffs to invest carefully, the Court promotes the anti-fraud policies of the [Securities and Exchange] Acts and engenders stability in the markets."228 Increased diligence discourages securities fraud because the incentives to engage in illegal activity decrease as the probability of discovery and disclosure increases. ${ }^{229}$

Second, encouraging due diligence serves the underlying purposes of the securities laws. By making the detection of fraud more likely, a regime which emphasizes due diligence serves to deter would-be wrongdoers. For those individuals who persist in engaging in securities fraud, due diligence increases the likelihood of detection and, therefore, makes it easier to disgorge ill-gotten gains and compensate the victims of securities fraud. Many of the objectives of securities laws are interrelated and are sometimes satisfied as a package. Procedural changes which encourage due diligence represent a way to achieve several related objectives simultaneously.

Equitable tolling creates two independent but related incentives for

225. Woolf v. S.D. Cohn \& Co., 521 F.2d 225, 227 (5th Cir. 1975).

226. See, e.g., UNIFORM LIMITED PARTNERSHIP ACT $\S 305$ (1985), 6 U.L.A. 356 (Supp. 1992).

227. Stephenson v. Paine Webber Jackson \& Curtis, Inc., 839 F.2d 1095, 1099 (5th Cir.) (citing Straub v. Vaisman \& Co., 540 F.2d 591, 597 (3d Cir. 1976)), cert. denied, 488 U.S. 926 (1988).

228. Dupuy v. Dupuy, 551 F.2d 1005, 1014 (5th Cir.), cert. denied, 434 U.S. 911 (1977).

229. Tew v. Chase Manhattan Bank, N.A., 728 F. Supp. 1551, 1567, amended, 741 F. Supp. 220 (S.D. Fla. 1990). 
investors to act with due diligence. First, if investors perform due diligence and discover fraud, they are able to sue and seek compensation in court. Second, even if investors find no fraud, they preserve the right to pursue legal action in the future if there was concealed fraud: their due diligence tolls the statute of limitations on the underlying Rule 10b-5 cause of action. Thus, in addition to helping discover causes of action, due diligence acts as an insurance policy to bring suit later if there is fraud. By eliminating equitable tolling in Rule 10b-5 cases, Lampf decreased both of these incentives for plaintiffs to exercise due diligence.

Equitable tolling encourages investors to be alert. The level of due diligence that is necessary to preserve a plaintiff's ability to bring suit is substantial because "the law demands that a Plaintiff not sleep on his rights, or ${ }^{\circ}$ close his eyes in stubborn refusal to see the truth, and later complain that he has been tricked and defrauded."230 The courts are not reluctant to impute knowledge of securities fraud to a plaintiff. The Second Circuit has held that,

where the circumstances are such as to suggest to a person of ordinary intelligence the probability that he has been defrauded, ... if he omits that inquiry when it would have developed the truth, and shuts his eyes to the facts which call for investigation, knowledge of the fraud will be imputed to him. ${ }^{231}$

Courts have delineated a number of factors which should provide "storm warnings" and thus create a duty to investigate. These factors include differences between an offering memorandum and the seller's oral representations, ${ }^{232}$ declining earnings or operating losses, ${ }^{233}$ a sharp drop in a security's market price, ${ }^{234}$ and an issuer's default in making bond payments at maturity. ${ }^{235}$

The argument can be made that eliminating equitable tolling encourages investors to exercise due diligence within the first three years of the sale of a security. There are three flaws in this argument. First, without tolling, due diligence loses its insurance value. Under the Lampf rule, due diligence has value only if the investors actually discover the fraud. But securities fraud is inherently difficult to detect. The wrongdoers hold all the cards. Although the Lampf rule does not further discourage due diligence among those investors who do not ordinarily exercise such care, the new rule does discourage due diligence among those investors who appreciate the insurance value of due diligence and

230. Armbrister v. Roland Int'l Corp., 667 F. Supp. 802, 825 (M.D. Fla. 1987).

231. Armstrong v. McAlpin, 699 F.2d 79, 88 (2d Cir. 1983) (quoting Higgins v. Crouse, 42 N.E. 6,7 (N.Y. 1895)).

232. Kennedy v. Josephthal \& Co., 814 F.2d 798, 803 (1st Cir. 1987).

233. Buder v. Merrill Lynch, Pierce, Fenner \& Smith, Inc., 644 F.2d 690, 692-93 (8th Cir. 1981).

234. Hupp v. Gray, 500 F.2d 993, 997 (7th Cir. 1974).

235. Loveridge v. Dreagoux, 678 F.2d 870, 875 (10th Cir. 1982). 
would otherwise make reasonable inquiries after receiving storm warnings.

Second, as the next Section argues, eliminating equitable tolling encourages wrongdoers to engage in fraudulent concealment. Securities fraud will thus be harder to detect, and investors may be more despondent about the value of investigating in the first place.

Finally, instead of encouraging earlier due diligence, the Lampf rule could encourage "insurance suits." 236 If due diligence no longer serves as insurance to toll the statute of limitations, the only way an investor can preserve her right to bring suit is to sue early, at the first sign of trouble. For example, if the price of a security drops unexpectedly two years and eleven months after purchase, the nervous (and perhaps even the prudent) investor might bring suit immediately. There is no time to investigate or exercise due diligence now, because in thirty days all private Rule 10b-5 claims will be barred, permanently. The lack of any alternative means of tolling the statute of limitations could provoke "false starts" whereby investors sue lest they forfeit their rights due to inaction. Due diligence provides a more efficient mechanism to preserve the right to sue. ${ }^{237}$

\section{d. The Lampf Rule Encourages Fraudulent Concealment}

Eliminating equitable tolling rewards the successful wrongdoer who escapes detection for three years. Given the complexity of many securities fraud schemes, such evasion is not difficult. Commentators have noted that under a three-year repose rule, "a 10b-5 violator could avoid liability merely by engaging in a continuing fraud to cover up the existence of the original violation."238 There is no incentive to refrain from fraudulent concealment because it does not give rise to additional liabil-

236. If this actually were to happen, it would be ironic given that one of hidden reasons behind the Supreme Court's imposition of a short statute of repose may have been to reduce the burgeoning number of private Rule 10b-5 cases. Indeed, in many of the Court's decisions since the mid-1970s, one sees a steady trend towards increasing the requirements on plaintiffs. For example, Blue Chip Stamps v. Manor Drug Stores, 421 U.S. 723 (1975), which restricted Rule 10b-5 to actual purchasers or sellers of securities, greatly limited the number of potential cases. The Third Circuit explained that " $[t]$ he judiciary having created a private cause of action [under Rule 10b-5] soon sensed a need to limit and define it." Straub v. Vaisman \& Co., 540 F.2d 591, 597 (3d Cir. 1976). The imposition of stricter requirements of materiality, reliance, and scienter has all been part of the process of limiting the number of Rule $10 \mathrm{~b}-5$ suits. See id. ("The courts thus sought to deter investor carelessness in securities transactions and also reduce the number of claims, a trend reflected in other areas as well." (footnote omitted)).

237. Of course, in theory an incentive structure could be created that encouraged excessive due diligence. Excessive due diligence occurs when society invests more resources in due diligence efforts than the expected returns of such monitoring. However, since there was no evidence of overmonitoring during the 45 years that equitable tolling was the rule, this does not appear to be a pressing problem.

238. 2 HAZEN, supra note $71, \S 13.8$, at 132 . 
ity. The limitations period begins when the securities are sold; ${ }^{239}$ subsequent activity (unless it constitutes a separate investment) will not start the statute of limitations running anew. If the fraudulent concealment is somehow discovered, it is merely collapsed into the original securities fraud scheme. No additional penalties are assessed. Under the current rule, it would be irrational not to engage in ongoing fraud. Thus, Lampf undermines the philosophy of full disclosure which underlies American securities regulation. ${ }^{240}$

In addition to the initial securities fraud, ongoing fraudulent concealment impedes the efficiency of securities markets by delaying the disclosure of material information. Securities markets operate most efficiently when full and accurate information is disseminated. Securities fraud schemes which take longer to discover and expose distort the market more than readily exposed schemes. The Lampf rule delays dissemination of this information by decreasing the incentive for plaintiffs to exercise due diligence ${ }^{241}$ and by increasing the incentive for wrongdoers to fraudulently conceal the initial fraud from the market.

An argument can be made that the three-year statute of repose might hasten discovery because wrongdoers will be more forthcoming about their wrongdoing after the three-year period expires. However, wrongdoers have no incentive to confess their conduct: they have nothing to gain, and, while private suits have been foreclosed, the SEC could still bring action. ${ }^{242}$ Further, after three years of fraudulent concealment, it is unlikely that outside investigation will uncover any wrongdoers' schemes. Private individuals have little incentive to investigate because no matter what they find, they cannot bring suit after three years have elapsed. And the SEC, with its limited resources, is not likely to start an investigation at this late stage. With no investigation in sight, the need for active concealment abates, and the wrongdoers may safely consolidate their profits and move on to further financial shenanigans.

Of course, even with equitable doctrines there is an incentive for fraudulent concealment because if the plaintiffs never discover the fraud, they cannot bring suit. But a lifetime of fraudulent concealment might be expensive. Under the current rule, defendants need only actively conceal their fraud for three years, a less costly venture. Without equitable tolling, the total cost of fraudulently concealing the initial fraud shrinks. Thus, fraudulent concealment represents a more cost-effective strategy for wrongdoers in the absence of equitable doctrines.

239. Suslick v. Rothschild Sec. Corp., 741 F.2d 1000, 1005 (7th Cir. 1984).

240. See supra note 166.

241. See supra notes $227-35$ and accompanying text.

242. See infra notes $265-68$ and accompanying text. 


\section{Compensating Victims}

The goal of compensation presupposes that the preliminary effort to deter securities fraud has failed. Of course, deterrence is not perfect. No matter how well any law is constructed and enforced, there will always be violations. Indeed, if the amount of securities fraud litigation is any indication, deterrence in securities regulation is far from adequate. Thus, a set of secondary objectives comes into play when securities fraud does occur. The overriding goal is to insure that the system never breaks down. When it does, the goal becomes compensating victims of securities fraud, often by making those who engage in securities fraud disgorge their profits.

The courts have long recognized that compensating defrauded investors is an important policy goal underlying the Exchange Act. Coupled with deterrence, compensating victims is an important function of Rule 10b-5. ${ }^{243}$ For example, the SEC may freeze the assets of wrongdoers in order to ensure that adequate funds are available to compensate victims of securities fraud. ${ }^{244}$

Eliminating equitable tolling and equitable estoppel inhibits the compensation of victims. The analysis parallels the deterrence discussion in many respects. First, creating new defenses reduces the likelihood of compensation. For every wrongdoer who successfully uses a new defense, at least one victim goes uncompensated. ${ }^{245}$ Again, there is an inherent trade-off between the risks of rewarding undeserving plaintiffs and not compensating deserving victims of securities fraud. However, rules can be developed that minimize the risk of unwarranted compensation while maintaining the advantages of equitable doctrines which minimize the second risk.

Second, because most securities fraud takes years to discover, a three-year statute of repose will prevent compensation of many legitimate victims. Even when sophisticated investors exercise due diligence, they will often fail to discover securities fraud. ${ }^{246}$ This is illustrated by specific examples where plaintiffs are unlikely to discover the fraud in three years and therefore will never receive any compensation. ${ }^{247}$ Even if the SEC brings suit later, the original victims will receive no compensation. SEC actions are usually limited to making wrongdoers disgorge illegal

243. Woolf v. S.D. Cohn \& Co., 521 F.2d 225, 227 (5th Cir. 1975).

244. International Controls Corp. v. Vesco, 490 F.2d 1334, 1347 (2d Cir.) (citing SEC v. Manor Nursing Ctrs., Inc., 458 F.2d 1082, 1105-06 (2d Cir. 1972)), cert. denied. 417 U.S. 932 (1974).

245. Of course, some defendants would win on the merits anyway, so the new defense would not affect the outcome in all cases.

246. Lampf, Pleva, Lipkind, Prupis \& Petigrow v. Gilbertson, 111 S. Ct. 2773, 2789 (1991) (Kennedy, J., dissenting). Also, plaintiffs are unlikely to increase their due diligence efforts in the first three years after the date of sale. See supra notes 227.37 and accompanying text.

247. For types of Rule 10b-5 misconduct that are unlikely to be discovered in three years under the Lampf rule, see supra notes $189-226$ and accompanying text. 
gains, and are not intended to compensate victims. ${ }^{248}$ Furthermore, although SEC actions may alert private victims to Rule $10 \mathrm{~b}-5$ violations, SEC investigations often will not assist private claimants because the SEC usually takes more than two years to investigate wrongdoing. ${ }^{249}$ Thus, many SEC actions will not alert the public until after the threeyear window has closed. In sum, a three-year statute of repose will prevent many victims of securities fraud from receiving compensation for their injuries.

\section{Disgorging Ill-Gotten Gains}

As with the goal of compensation, disgorging ill-gotten gains comes into play when efforts to prevent securities fraud have failed. Securities laws should ensure that wrongdoers do not profit from their illegal activity. Disgorging ill-gotten gains is an important aspect of securities regulation for two reasons. First, there is a fairness principle that "cheaters shouldn't prosper."2so Disgorging ill-gotten gains is therefore an equitable doctrine in and of itself. ${ }^{251}$ Second, disgorging ill-gotten gains enhances deterrence by decreasing the potential benefits of securities fraud. The more likely the detection and disgorgement of illegal profits, the less likely people will engage in securities fraud in the first place.

Section 16(b) and the more recent federal legislation on insider trading illustrate that disgorging ill-gotten gains is a goal of American securities laws. Section 16(b) automatically makes controlling persons disgorge all profits (or losses avoided) for trades they make within any six-month period. ${ }^{252}$ The Insider Trading and Securities Fraud Enforcement Act was explicitly designed to make wrongdoers disgorge profits (or losses avoided). ${ }^{253}$ The federal courts have consistently held that disgorging ill-gotten gains is an important goal of the securities laws. ${ }^{254}$ Some courts have held that the proper measures of damages in private suits is the disgorgement of profits. ${ }^{255}$

248. List v. Fashion Park, Inc., 340 F.2d 457, 463 (2d Cir.), cert. denied, 382 U.S. 811 (1965); SEC v. Randolph, 564 F. Supp. 137, 141 (N.D. Cal. 1983), rev'd on other grounds, 736 F.2d 525 (9th Cir. 1984).

249. See supra note 183 and accompanying text.

250. See SEC v. Wang, 944 F.2d 80, 81 (2d Cir. 1991).

251. Id.; SEC v. Great Lakes Equities Co., [1990-1991 Transfer Binder] Fed. See. L. Rep. (CCH) I 95,685, at 98,220 (E.D. Mich. Sept. 4, 1990), appeal dismissed, 933 F.2d 1009 (6th Cir. 1991) (unpublished opinion).

252. Section $16(\mathrm{~b})$ creates an irrebuttable presumption that gains within a six-month period are ill-gotten and must be disgorged.

253. Exchange Act $\S 20 \mathrm{~A}(\mathrm{~b})(1), 15$ U.S.C. $\S 78 \mathrm{t}-1(\mathrm{~b})(1)(1988) ; 2$ HAZEN, supra note 71 , $\S 13.8$, at 133 .

254. See SEC v. Materia, 745 F.2d 197, 200-01 (2d Cir. 1984) (affirming disgorgement of illgotten gains in Rule 10b-5 case using misappropriation theory), cert. denied, 471 U.S. 1053 (1985); SEC v. Manor Nursing Ctrs. Inc., 458 F.2d 1082, 1104 (2d Cir. 1972) (affirming disgorgement of illgotten gains).

255. Elkind v. Liggett \& Myers Inc., 635 F.2d 156, 173 (2d Cir. 1980); Ohio Drill \& Tool Co. v. 
Equitable tolling and equitable estoppel facilitate the disgorging of ill-gotten profits by helping both private and government suits. This is illustrated in two ways. First, disgorging ill-gotten gains is the flip side of compensation. When wrongdoers pay their victims for the harm they have inflicted, the money comes out of their illegal profits. ${ }^{256}$ To the extent that equitable doctrines facilitate compensation, they simultaneously facilitate disgorging illegal gains.

Second, equitable tolling facilitates SEC enforcement. Even though the SEC is not subject to the three-year statute of repose, the ability of private claimants to bring suit after three years affects SEC enforcement effectiveness. Eliminating equitable tolhing decreases the probability that the SEC will discover and prosecute securities fraud violations because it discourages private citizens from investigating potential fraud. Private investigations and litigation can alert the SEC to the possibility of fraud. Given sufficient incentives to exercise due diligence, private citizens can perform many of the investigative functions of the SEC. ${ }^{257}$ Eliminating equitable tolling reduces these incentives. By contrast, preserving equitable tolling facilitates detection of securities fraud. When private citizens detect securities fraud, the SEC can prosecute and compel wrongdoers to disgorge illegal gains. ${ }^{258}$ To the extent that equitable doctrines help both private and government suits, they facilitate disgorging ill-gotten gains and consequently enhance deterrence.

\section{B. The Purposes of Statutes of Repose}

There are three general justifications for imposing a statute of repose. ${ }^{259}$ First, out of fairness, potential defendants are entitled to a sense of repose after a reasonable amount of time has passed. Second, evidence goes stale over time and makes litigation impractical and unfair. Third, statutes of repose facilitate business certainty and planning. Statutes of limitations are important in securities fraud. This Comment does not seek to downplay their utility in extinguishing stale claims and providing stability and fairness for all would-be defendants. Rather, this Comment argues that statutes of repose are inappropriate in Rule 10b-5

Johnson, 498 F.2d 186, 190-91 (6th Cir. 1974); Zeller v. Bogue Elec. Mfg. Corp., 476 F.2d 795, 80103 (2d Cir.), cert. denied, 414 U.S. 908 (1973).

256. Because the transaction costs of securities fraud are probably positive, full compensation should wipe out all profits and then some.

257. See Stephenson v. Paine Webber Jackson \& Curtis, Inc., 839 F.2d 1095, 1099 (5th Cir.) (citing Straub v. Vaisman \& Co., 540 F.2d 591, 597 (3d Cir. 1976)), cert. denied, 488 U.S. 926 (1988).

258. Note that even with successful SEC prosecution, there is no compensation for private victims. See supra note 248 and accompanying text.

259. The Lampf Court did not lay out these arguments because it did not discuss the wisdom of imposing a statute of repose at all. Lampf, Pleva, Lipkind, Prupis \& Petigrow v. Gilbertson, 111 S.Ct. 2773, 2781-82 (1991). 
cases $^{260}$ because courts developed Rule $10 \mathrm{~b}-5$ private actions under the assumption that they were not governed by a statute of repose. Other protections were instead built into Rule $10 \mathrm{~b}-5$ to achieve these objectives. Furthermore, the general purposes of limitations periods are not compromised by equitable doctrines. ${ }^{261}$ Indeed, almost all federal statutes of limitations have had equitable tolling read into them. ${ }^{262}$

\section{Fairness to Defendants}

The traditional objective of statutes of repose is fairness. Fairness is an elusive criterion; there are no clear standards for what constitutes "fairness." Like obscenity, most people know it when they see it. Unfortunately, as with obscenity, one person's fairness is another's atrocity. Courts must balance fairness to competing parties. Fairness to potential defendants, the protection against stale claims, must be balanced against fairness to plaintiffs, who deserve compensation. when they are defrauded.

Congress, when enacting the securities acts, believed that at a certain point would-be defendants are entitled to a sense of repose. In the initial debates on the Exchange Act, Senator Fletcher argued that if the injured party "has not discovered [the fraud], the person who made the misrepresentation or false statement ought to feel safe at some reasonable time that he will not be disturbed."263 Three years may have seemed like a reasonable time for the specific offenses that the 1930s Congress addressed, but the securities fraud of today is more complicated, more cunning, and harder to detect than the misdeeds of previous generations. Having three years to discover a complex securities fraud scheme suggests a Kafkaesque version of "Beat the Clock," where the contestants are not even sure for what they are looking.

The argument that fairness to potential defendants requires plaintiffs to discover Rule 10b-5 fraud and bring suit within three years is flawed for five reasons. First, this argument reasons that it is unfair to allow plaintiffs to sit on a claim and leave it hanging over potential defendants like a sword of Damocles. ${ }^{264}$ This misses the point: the plaintiffs are not

260. This may promnt the question why statutes of repose are appropriate for actions brought under $\S \S 9,11$, and 12 of the Securities Act and $\S 16$ of the Exchange Act. For a discussion of this distinction, see infra Part III.C.

261. This Comment sometimes impliedly assumes that equitable tolling doctrine is applied accurately. While in theory equitable tolling may be applied in error, many safeguards are built into the doctrine to prevent plaintifis from sitting on their rights. For example, the pleading and particularity standards for equitable tolling are quite stringent. See infra notes 293-300 and accompanying text.

262. See infra notes 318-19.

263. Walck v. American Stock Exch., Inc., 687 F.2d 778, 792 (3d Cir. 1982) (quoting 78 CoNG. REC. 8198 (1934) (remarks of Sen. Fletcher)), cert. denied, 461 U.S. 942 (1983).

264. The Greek myth of Damocles centers around his being made to sit through a banquet with a sword suspended by a hair over his head. 
simply sitting on a claim; rather, they are unaware that the claim exists. Only the wrongdoers know a potential violation has occurred. If a sword of Damocles does hang, it was put in place by the wrongdoers, and the other diners are oblivious to its presence. If a defendant fraudulently conceals her crime, she is in control, not the plaintiff. Even with equitable tolling, if the plaintiff has reason to believe there may have been a violation of Rule $10 \mathrm{~b}-5$, she has only one year to bring suit. There is no risk that plaintiffs will taunt potential defendants with unending liability.

Second, even with the current statute of repose, potential defendants are not likely to achieve a state of true repose because Lampf only limits private causes of action. ${ }^{265}$ The general rule is that a federal government plaintiff is not bound by any limitations period unless Congress explicitly provides that the government is so bound. ${ }^{266}$ This rule has even been applied to exempt government plaintiffs from limitations provisions which on their face apply to "all actions."267 Specifically, the Court in Lampf impliedly limited its holding to "private suit[s] brought pursuant to section 10(b)."268 This makes sense because section 9 of the Securities Act, from which the Court borrowed the statute of limitation for Rule 10b-5 actions, does not apply to suits brought by federal actors. Thus, the SEC can still bring suit when private follow-on suits are precluded. Even though the SEC is less likely to bring suit than a private plaintiff, repose is a function of possibility, not probability. The potential defendant does not receive a "fresh start." The possibility of suits still hangs over potential defendants, yet victims are less likely to be compensated.

Third, although private claimants cannot sue for Rule 10b-5 violations after three years, they often can continue to litigate the underlying securities fraud by bringing suit under a different cause of action. For example, in a case involving both securities and $\mathrm{RICO}^{269}$ claims, the civil RICO claim may be brought independently. RICO requires two or more predicate acts to constitute the requisite "pattern of racketeering activity," and the statute specifically defines "fraud in the sale of securities" as a predicate offense. ${ }^{270}$ Indeed, according to the ABA's Civil RICO Task

265. SEC v. Rind, 991 F.2d 1486, 1489-90 (9th Cir. 1993).

266. United States v. Tri-No Enters., 819 F.2d 154, 158 (7th Cir. 1987).

267. E.I. DuPont de Nemours \& Co. v. Davis, 264 U.S. 456, 462 (1924); see also Badaracco v. Commissioner, 464 U.S. 386, 391 (1984) (reaffirming DuPont's holding that statutes of limitation are strictly construed in favor of the government).

268. Lampf, Pleva, Lipkind, Prupis \& Petigrow v. Gilbertson, 111 S. Ct. 2773, 2776 (1991).

269. RICO is the Racketeer Influenced and Corrupt Organizations Act, codified at 18 U.S.C. $\S \S 1961-1968$ (1988). Civil RICO refers to 18 U.S.C. $\$ 1964(c)$, which trebles damages for private plaintiffs.

270. 18 U.S.C. $\S 1961$ (1) (1988); see, e.g., In re National Mortgage Equity Corp. Mortgage Pool Certificates Sec. Litig., 636 F. Supp. 1138, $1157-59$ (C.D. Cal. 1986) (applying 18 U.S.C. $\S 1961$ ). It is not yet clear whether civil RICO's securities fraud predicate offense embraces all securities fraud covered by Rule 10b-5. Moss v. Morgan Stanley, Inc., 719 F.2d 5, 18 n.14 (2d Cir. 1983), cert. denied, 465 U.S. 1025 (1984). 
Force Report, thirty-five percent of civil RICO claims "relied solely or primarily on allegations of securities fraud." $" 271$ Civil RICO cases have a four-year statute of limitations ${ }^{272}$ which is generally subject to equitable tolling. ${ }^{273}$ Therefore, civil RICO can be used to circumvent an overly restrictive limitations period for Rule 10b-5 cases. ${ }^{274}$ The same reasoning applies to cases involving securities fraud in connection with a number of other potential federal causes of action, such as antitrust, which are subject to equitable tolling. For example, if the behavior at issue can be characterized as insider trading, a complaint based on insider trading under section $20 \mathrm{~A}$, enacted in 1988 , is governed by a fiveyear statute of limitations. ${ }^{275}$ Not only does this give the plaintiff more time, but section $20 \mathrm{~A}$ may be subject to equitable tolling. ${ }^{276}$ In both situations, defendants enjoy no repose because the securities fraud may ultimately be litigated with the Rule 10b-5 language eliminated. ${ }^{277}$

Similarly, plaintiffs can repackage their grievances as state claims and circumvent the federal statute of repose. ${ }^{278}$ While the availability of state blue sky laws may be a benefit to some potential victims of securities fraud, primary reliance on state law may create the exact problem Lampf set out to alleviate-nonuniformity. State blue sky laws have different requirements. Victims of the same securities fraud living in different states would be treated differently. For example, if investors living in Maryland, Arkansas, and Illinois all bought fraudulent securities from a

271. Arthur F. Mathews, Shifting the Burden of Losses in the Securities Markets: The Role of Civil RICO in Securities Litigation, 65 NOTRE DAME L. Rev. 896, 930 (1990) (citing Mathews, Report of the Ad Hoc Civil RICO Task Force, A.B.A. SEC. CoRp. BANking \& Bus. L. 57 (1985)). Mathews notes that "[a]lthough there has not been a comprehensive survey of civil RICO cases since the publication of the ABA Task Force Report, there is reason to believe the figures have remained substantially the same." Id. at 930 n. 177 .

272. Agency Holding Corp. v. Malley-Duff \& Assocs., Inc., 483 U.S. 143, 156 (1987).

273. "Every court that has considered an accrual rule for civil RICO has adopted some sort of discovery rule." McCool v. Strata Oil Co., 972 F.2d 1452, 1465 (7th Cir. 1992).

274. Mathews, supra note 271, at 938 ("[A] civil RICO plaintiff may be given more time to commence a damages action than the applicable 1933 and 1934 Acts provisions allow.").

275. Section 20A, 15 U.S.C. $\$ 78 t-1(b)(4)$ (1988), was added by the Insider Trading and Securities Fraud Enforcement Act of 1988, Pub. L. No. 100-704, § 5, 102 Stat. 4677, 4680.

276. See Short v. Belleville Shoe Mfg. Co., 908 F.2d 1385, 1391-92 (7th Cir. 1990) ("[Section $13]$ is a statute of repose, while $\S 20 \mathrm{~A}$ appears to be a statute of limitations."), cert. denied, $111 \mathrm{~S}$. Ct. 2887 (1991).

277. This ultimate lack of repose may prompt the argument that little is lost when some plaintiffs can no longer use Rule 10b-5, because they can simply shift to civil RICO. While this may provide solace to some individual plaintiffs, from a policy standpoint this is an unattractive development. First, civil RICO has its own requirements and, thus, not all Rule 10b-5 plaintiffs will be able to plead civil RICO. For example, the wrongdoer may not have engaged in two or more instances of securities fraud, or the plaintiff may be unable to prove the operation of an enterprise. Second, it is better to have Rule $10 \mathrm{~b}-5$ operate properly than to have its absence be easily circumvented. The legal system should encourage plaintiffs to litigate securities fraud as securities fraud, not as racketeering.

278. Sherry R. Sontag, Time May Not Be on Their Side, NAT'L L.J., Dec. 31, 1990, at 1, 24 ("If his clients lose their recourse under the federal securities laws, [the attorney] says he will refile the claims in numerous state courts."). 
wrongdoer in California, each would have a different length of time in which to bring suit, even if they all bought the same stock at the same price and suffered the same damage. The Maryland investors would have to sue within one year from discovery and three from sale; ${ }^{279}$ the Arkansas investors, within five years froin sale; ${ }^{280}$ and the Illinois investors, within three years from discovery and five from sale. ${ }^{281}$ This hardly seems fair. Reliance on this patchwork of state laws represents the worst of both worlds: potential defendants are denied repose and potential plaintiffs are denied uinform protection. A federal statute of linitations that incorporates equitable principles solves both probleins.

Fourth, even if one were to accept the premise that at some point, a single instance of misconduct should not haunt a person forever, equitable tolling and equitable estoppel only corne into play when the defendant intentionally conceals her fraud or otherwise misleads her victim. To the extent that defendants deserve the protection of statutes of limitations, rules can be fashioned that achieve the benefits of equitable doctrines while also protecting defendants against unfair suits. ${ }^{282}$ For example, equitable estoppel requires that the defendant affirmatively lull the plaintiff into not bringing suit. The plaintiff must rely on the defendant's stateinents. Most importantly, the defendant inust intend to cause the plaintiff's reliance. This intent requirement ensures that defendants have engaged in wrongdoing subsequent to the initial violation. Similarly, equitable tolling inay require fraudulent concealinent such that the defendants have misbehaved after the initial violation which activates the three-year clock. ${ }^{283}$

Finally, a strong argument can be made that fairness favors the adoption of equitable doctrines for would-be plaintiffs under Rule 10b-5. In 1988, Congress created the Federal Courts Study Committee, which performed a complete analysis of the federal court systein and recommended uniforn limitations periods for federal causes of action. ${ }^{284}$ The Cominittee recommended that the fraudulent concealment doctrine be maintained, concluding that "[f]airness argues against rewarding wrongdoers who succeed in concealing their inisdeed long enough, and the difficulties of making out a case of fraudulent concealment protect against widespread abuse of the doctrine."285 It is simply unfair to deny access to the courts to victims of securities fraud who, through no fault of their

279. MD. CORPS. \& ASS'NS CODE ANN. § 11-703(f) (1993).

280. ARK. CODE ANN. § 23-42-106(f) (Michie 1987).

281. ILL. ANN. Stat. ch. 121 1/2 para. 137.13D (Smith-Hurd Supp. 1992).

282. See infra Part IV.A.

283. See supra notes $26-27$ and accompanying text. Violations which entail self-concealing fraud are more tricky, but again reasonable rules can be tailored to this situation. See infra note 336 and accompanying text.

284. See Report of the Federal Courts Study Committee 31, 93 (1990).

285. Id. at 93-94. 
own, are unaware that they have been wronged until it is too late to bring suit. Investors are penalized for circumstances beyond their control. Caveat Emptor has been replaced by Fraudetur Emptor: "Let the Buyer be Defrauded."286 This is most apparent in the case of adverse domination. In this case, even the most diligent investors cannot know that they have a potential cause of action, let alone bring suit, within the limited window of opportunity - the defendants control all of the relevant information as well as the entity that should have brought suit. ${ }^{287}$ This fairness argument goes beyond the compensation rationale for requiring equitable tolling, because the victims are denied not only their compensation, but also their day in court.

A similar fairness argument can be advanced for re-instituting equitable estoppel in Rule 10b-5 cases. The philosophy behind equitable estoppel is "that a wrongdoer cannot take advantage of his wrongdoing."288 The current rule turns this principle on its head. One sure way to avoid private suits is to acknowledge the initial wrongdoing and discuss compensation with the victims until the limitations period has expired. The simplicity of this tactic could encourage sham negotiations in which defendants back out of negotiations after it is too late for the plaintiffs to bring suit. Wrongdoers not only benefit from this further misconduct, but it is encouraged; it creates an absolute defense.

\section{Barring Stale Claims}

One of the principal rationales for maintaining statutes of repose is to prevent litigation based on stale evidence. In securities cases, this concern is greatly diminished by a number of factors. First, the paper trail is less likely to be obscured. Even if memories fade, securities fraud cases live and die on the paper record. ${ }^{289}$ Potential defendants, including brokerage houses, corporations, underwriters, dealers, and individual traders, are already required to create and maintain extensive records

286. To describe the pre-Lampf state of law as caveat emptor downplays the relatively high level of protection afforded to securities buyers. Rule 10b-5 and equitable doctrines exist because even the most prudent investor may not be able to protect herself against the innovative fraud artist. The Supreme Court explained that "[a] fundamental purpose [behind the securities laws] . . . was to substitute a philosophy of full disclosure for the philosophy of caveat emptor and thus to achieve a high standard of business ethics in the securities industry." SEC v. Capital Gains Research Bureau, Inc., 375 U.S. 180, 186 (1963).

287. See also supra text accompanying note 282; infra Part IV.A.

288. Barton v. Peterson, 733 F. Supp. 1482, 1490 (N.D. Ga. 1990) (citing Glus v. Brooklyn E. Dist. Terminal, 359 U.S. 231 (1959); Cook v. Deltona Corp., 753 F.2d 1552 (11th Cir. 1985); Sanchez v. Loffland Bros. Co., 626 F.2d 1228 (5th Cir. 1980), cert. denied, 452 U.S. 962 (1981); Bomba v. W.L. Belvidere, Inc., 579 F.2d 1067 (7th Cir. 1978)).

289. This is particularly true in the ease of class action suits alleging securities fraud. Federal Rule of Civil Procedure 23 requires that "common questions predominate" so "[s]ecurities class actions seldom involve disputes about what was said, because the claims involve public, written statements." Janet C. Alexander, Do the Merits Matter? A Study of Settlements in Securities Class Actions, 43 StAN. L. Rev. 497, 527 \& n.105 (1991). 
regarding securities transactions. For example, section 13(b)(2) of the 1934 Act requires publicly traded companies to maintain books, records, and accounts that reflect the corporation's transactions, acquisitions, and dispositions of assets. Also, sections 13(a), (d), and (e), 15(d), 16(a), and $17 \mathrm{~A}$ contain reporting or record requirements. In addition to the requirements under the Securities and Exchange Acts, the Commodity Futures Trading Commission requires brokerage houses to keep accurate records on employees' orders. ${ }^{290}$ These records are often determinative in Rule 10b-5 cases. For example, in churning cases, the relevant records consist almost exclusively of the trading data, ${ }^{291}$ which traders are already required to maintain. Thus, although there is a legitimate concern that defendants may throw away an exculpatory piece of paper, this is not a significant problem in the case of securities fraud. Current regulations require that records be maintained for a long time. ${ }^{292}$ Modern information technology makes retaining large records relatively easy. Indeed, purging files probably requires more effort than simply maintaining them.

Second, plaintiffs must plead fraud with particularity. All claims under section 10(b) of the Exchange Act must meet the pleading requirements of Federal Rule of Civil Procedure 9(b). ${ }^{293}$ Rule 9(b) requires that "[i]n all averments of fraud or mistake, the circumstances constituting fraud or mistake shall be stated with particularity."294 In the context of securities fraud, the particularity requirements are particularly particular:

In order to plead fraud with particularity, "a complaint must adequately specify the statements it claims were false or misleading, give particulars as to the respect in which plaintiff contends the statements were fraudulent, state when and where the statements were made, and identify those responsible for the statements." Such allegations cannot be conclusory, but must be supported by assertions of fact. ${ }^{295}$

290. 17 C.F.R. $\S \S 1.31-39$ (1992) (providing record-keeping requirements of the Commodity Futures Trading Commission).

291. See Armstrong v. McAlpin, 699 F.2d 79, 91 (2d Cir. 1983) (identifying churning as "excessive rate of turnover" of stock holdings in order to generate commissions.).

292. See Louis Loss \& Joel Seligman, Securities Regulation 3107-16 (3d ed. 1991).

293. Farley v. Baird, Patrick \& Co., 750 F. Supp. 1209, 1217 (S.D.N.Y. 1990).

294. FED. R. CIV. P. 9(b). However, there is a tension between the particularity requirements of Rule $9(\mathrm{~b})$ and the brevity requirements of Federal Rule of Civil Procedure 8(a) which requires "a short and plain statement of the claim" for relief. The balance is struck by providing as "much detail [as] is necessary to give adequate notice to an adverse party and enable him to prepare a responsive pleading." Dahl v. Gardner, 583 F. Supp. 1262, 1267 (C.D. Utah 1984) (quoting 5 Charles A. Wright \& Arthur R. Miller, Federal Practice and Procedure $\$ 1298$ (1969)).

295. Farley, 750 F. Supp. at 1217 (quoting Cosmas v. Hassett, 886 F.2d 8, 11 (2d Cir. 1989); citing Luce v. Edelstein, 802 F.2d 49, 54 (2d Cir. 1986)); see also Armstrong, 699 F.2d at 88 
The particularity requirements also apply to the element of scienter in Rule 10b-5 cases. Under Rule 9(b), "plaintiffs must at least present those circumstances that provide a minimal factual basis for allegations of scienter,"296 and must "plead facts that support a 'strong inference' that defendants possessed the requisite fraudulent intent."297 Plaintiffs bear further pleading burdens when they seek to toll a statute of limitations. One court held that plaintiffs "must plead with at least some particularity why they did not know the securities should have been registered, when they discovered registration was required, what circumstances or events led to that discovery and why they did not discover those facts earlier."298

Plaintiffs can only meet Rule 9(b) particularity requirements based on information and belief "if the pertinent information is so peculiarly within a defendant's knowledge that plaintiff caunot be expected to plead other than upon information and belief. Even in this situation, plaintiff must state the facts upon which plaintiff's belief is founded."299

The level of required particularity rises further when the defendant moves for summary judgment. Under federal law, in order to survive a motion for summary judgment, the plaintiff must present evidence regarding the time and circumstances of discovery of the fraud. ${ }^{300}$ This provides additional protection for defendants against potentially frivolous suits, including those which may be filed years after the accrual of the cause of action.

Third, the burden of proof is on the plaintiff to produce an evidentiary record sufficient to convince the finder of fact that Rule $10 \mathrm{~b}-5$ has been violated. Thus, if the evidentiary record is stale, the plaintiff is precluded from bringing suit. The defendant is not penalized for a weak paper trail. Furthermore, the requirement of reliance can protect

("Appellant's generalized and conclusory allegations of fraudulent concealment do not satisfy the requirements of Fed.R.Civ.P. 9(b).").

296. Farley, 750 F. Supp. at 1217 (quoting Eickhorst v. American Completion and Dev. Corp., 706 F. Supp. 1087, 1091 (S.D.N.Y. 1989)).

297. Id. (citing Beck v. Manufacturers Hanover Trust Co., 820 F.2d 46, 50 (2d Cir. 1987), cert. denied, 484 U.S. 1005 (1988), overruled on other grounds by United States v. Indelicato, 865 F.2d 1370 (2d Cir. 1989) (en banc)). Similarly, to invoke equitable tolling in a common law fraud suit, "Plaintiffs must show: first, that they failed to discover, and could not have discovered, the facts underlying their claim before the applicable statute ran, and second, that this was so because Defendants prevented Plaintiffs from discovering the facts by "fraudulent means." "Armbrister v. Roland Int'l Corp., 667 F. Supp. 802, 810 (M.D. Fla. 1987) (emphasis omitted). Judge Friendly explained further that plaintiffs must advance "distinct averments as to the time when the fraud, mistake, concealment, or misrepresentation was discovered, and what the discovery is, so that the court may clearly see, whether by the exercise of ordinary diligence, the discovery might not have been before made." Moviecolor Ltd. v. Eastman Kodak Co., 288 F.2d 80, 88 (2d Cir.), cert. denied. 368 U.S. 821 (1961) (quoting Stearns v. Page, 49 U.S. (7 How.) 819, 829 (1849)).

298. In re National Mortgage Equity Corp. Mortgage Pool, 636 F. Supp. 1138, 1167 (C.D. Cal. 1986) (emphasis omitted).

299. Farley, 750 F. Supp. at 1218 (citing Luce v. Edelstein, 802 F.2d 49, 54 (2d Cir. 1986)).

300. Briskin v. Ernst \& Ernst, 589 F.2d 1363, 1367 n.3 (9th Cir. 1978). 
defendants from accusations of oral misrepresentations. Rule 10b-5 requires that plaintiffs show their justifiable reliance on defendants' affirmative misrepresentations (or omissions of material fact) in deciding to buy or sell the security. ${ }^{301}$ The written record can trump oral representations. For example, in Zobrist v. Coal-X, Inc., ${ }^{302}$ the Tenth Circuit reasoned that in light of the private placement memorandum's explanation of the investment's risk, plaintiff did not justifiably rely on the defendant's alleged oral misrepresentations. ${ }^{303}$

Fourth, empirically stale evidence is not a problem. Equitable doctrines were applied to Rule $10 \mathrm{~b}-5$ cases for over forty years. The resulting case law does not suggest that lost evidence was an inherent, or even consistent, problem in securities fraud litigation.

\section{Business Certainty and Planning}

The final rationale for imposing statutes of repose is that they facilitate business planning by assuring executives that potential liabilities have expired. This level of certainty is assumed to help markets run more efficiently. The Seventh Circuit has noted that "[t]he legislative history in 1934 makes it pellucid that Congress included statutes of repose because of fear that lingering liabilities would disrupt normal business and facilitate false claims." 304 Both the securities laws as a whole and statutes of repose in particular share the objective of ensuring a smoothly operating securities market. However, re-adopting equitable doctrines better oils the wheels of the securities markets than maintaining a statute of repose for Rule 10b-5 actions.

The general argument that equitable doctrines in Rule 10b-5 cases interfere with business planning is unpersuasive. First, businesses can, and often do, plan for litigation. For example, when Ford marketed the Pinto with its faulty gas tank configuration, the company planned for possible lawsuits. ${ }^{305}$ Second, it sends a poor message to say that wrongdoers should get off the hook simply because they did not plan on getting caught, and punishing them now will disturb their business plans. Third, even when cases are filed in a timely manner, businesses still face substantial uncertainty because the ultimate resolution in securities cases takes an inordinately long time. ${ }^{306}$

301. Note, however, that reliance can be presumed in some cases under the fraud-on-the-market theory, see infra note 342, and when there is failure to disclose material information in face-to-face securities transactions, Affiliated Ute Citizens v. United States, 406 U.S. 128, 153-54 (1972); Shores v. Sklar, 647 F.2d 462, 472 (5th Cir. 1981) (en banc) (recognizing various situations in which reliance may be presumed), cert. denied, 459 U.S. 1102 (1983).

302. 708 F.2d 1511 (10th Cir. 1983).

303. Id. at 1518 .

304. Norris v. Wirtz, 818 F.2d 1329, 1332 (7th Cir.), cert. denied, 484 U.S. 943 (1987).

305. David Luban, LAWyers and Justice 206-10 (1988); W. KIP VISCUSI, Reforming Products Liability 111-13 (1991).

306. See, e.g., Anixter v. Home-Stake Prod. Co., 939 F.2d 1420, 1432 (10th Cir.) (13-year delay 
The current rule will probably hinder business planning in some cases by decreasing the utility of negotiations among litigants. Without equitable estoppel, plaintiffs should be less likely to enter negotiations of any kind. After all, equitable estoppel arises most often in the context of settlement negotiations. ${ }^{307}$ These settlement negotiations sometimes include tolling agreements in which potential litigants agree to toll a statute of limitations by separate contract. Tolling agreements are often used in litigation where, as in securities suits, complicated facts and relationships must be discovered and unraveled. ${ }^{308}$

Like any voluntary agreement, such arrangements are mutually beneficial. The would-be plaintiff receives time to investigate more thoroughly and evaluate whether she has a legitimate claim before bringing suit. If the plaintiff decides to go forward, she has lost nothing. If the plaintiff determines that she does not have a cause of action (at least not against this defendant), she saves legal fees.

The advantages for potential defendants are more obvious. Without the ability to agree to toll the statute of limitations, plaintiffs would be compelled to cast a wide net and sue all potential defendants in order to preserve any actions against the truly culpable. By agreeing to toll the statute of limitations, defendants enhance the probability that a plaintiff ultimately will decide not to bring suit against them. Thus, the net effect of tolling agreements is to provide greater stability in the litigation process and conserve scarce judicial resources.

The current state of the law decreases the likelihood that parties will enter into tolling agreements. Discouraging tolling agreements is bad policy for two reasons. First, plaintiffs may file suit simply to preserve rights that would otherwise expire, clogging courts' dockets and wasting judicial resources. ${ }^{309}$ Second, even sincere, honest businesses and defendants may be denied the option of entering tolling agreements because plaintiffs can never be sure that the agreement will be binding. ${ }^{310}$ The net effect is to eliminate an important form of planning and certainty for business-defendants.

from filing to judgment, not including years of subsequent appeals), modified, 947 F.2d 897 (10th Cir. 1991), vacated, 112 S. Ct. 1658 (1992).

307. See Gieringer v. Silverman, 731 F.2d 1272, 1278 (7th Cir. 1984).

308. See, e.g., Badger v. Boulevard Bancorp, Inc., 970 F.2d 410, 410 (7th Cir. 1992) (parties entered into tolling agreement after breakdown in negotiations concerning rescission of sale of interest in bank).

309. For a discussion of such "insurance" suits, see supra notes 236-37 and accompanying text

310. It is unclear whether an absolute bar that is not subject to equitable tolling and equitable estoppel can be tolled by an agreement between the parties. However, the circuit courts have held that the three-year bar is absolute; therefore, estoppel cannot be used to prevent defendants from pleading the statute of limitations. See supra note 155. 


\section{Why a Statute of Repose May Be Appropriate for the Express} Private Causes of Action Under the 1933 and 1934 Acts, But Not for Rule 10b-5

Arguing that Rule $10 \mathrm{~b}-5$ should not contain a statute of repose does not in any way indict congressional judgment. Applying equitable principles to Rule $10 \mathrm{~b}-5$ is not a rejection of congressional authority. Indeed, during most of Rule 10b-5's existence, congressional desires have been largely irrelevant. The judiciary created the private cause of action. ${ }^{311}$ The courts decided to apply the most analogous state statute of limitations $^{312}$ and federal equitable tolling. ${ }^{313}$ Finally, the Supreme Court decided to use the statute of limitations contained in section 9 of the 1934 Act. ${ }^{314}$

In establishing statutes of repose for the express private causes of action in the 1933 and 1934 Acts, Congress considered the risks of overand underdeterrence. Articulating the general dilemma of legal rules, Professor Einer Elhauge explained: "Any legal regime will accordingly err in two ways: (1) it will fail to detect and punish some undesirable conduct, and (2) it will mistakenly punish some desirable conduct. The first results in the underdeterrence of undesirable conduct; the second in the overdeterrence of desirable conduct." ${ }^{\text {315 }}$ If a limitations period is too short, there will be underdeterrence. The risk of underdeterrence exists for securities fraud because when wrongdoers are less likely to be held accountable for their misdeeds, they are more likely to engage in fraud in the first place. On the other hand, if a statute of limitations is too broad and open-ended, there is the risk of deterring beneficial conduct. Overdeterrence might result in qualified businesspeople declining to serve on boards of directors due to fear of lingering liabilities.

As Congress debated the 1933 and 1934 Acts, it became increasingly concerned with overdeterrence. The 1933 Act limitations periods were originally two years from discovery, with a ten-year period of repose. ${ }^{316}$ However, Congress shortened both periods when it amended the Securities Act in 1934. ${ }^{317}$ While these judgments may have been proper for the causes of action being debated at the time, there is no reason to apply the same reasoning to private actions brought under Rule 10b-5: these causes of action had not yet been imagined.

Because it may seem incongruous that Rule $10 \mathrm{~b}-5$ be subject to equi-

311. See supra notes 55-58 and accompanying text.

312. See supra notes $60-66$ and accompanying text.

313. See supra notes $80-82$ and accompanying text.

314. See supra notes 131-34 and accompanying text.

315. Einer Elhauge, The Triggering Function of Sale of Control Doctrine, 59 U. CHI. L. REv. 1465,1495 (1992).

316. Securities Act of 1933, ch. 38, § 13, 48 Stat. 74, 84 (amended 1934; current version at 15 U.S.C. $\S 77 \mathrm{~m}(1988))$.

317. Securities Exchange Act of 1934, ch. 404, § 207, 48 Stat. 881, 908. 
table tolling while the express causes of action under the 1933 and 1934 Acts are not, it bears repeating that statutes of repose for federal causes of action are relatively rare. There is a strong presumption that limitations periods do not constitute an absolute bar to suits. In the absence of clear congressional intent to the contrary, the doctrine of equitable tolling is read into all other federally created rights. ${ }^{318}$ For example, equitable tolling is read into antitrust violations under the Sherman Act and the Clayton Act, and racketeering under RICO. ${ }^{319}$ Statutes of repose are the exception, not the rule. Specifically, equitable tolling was read into Rule 10b-5 prior to Lampf.

The entire body of law surrounding the Rule 10b-5 cause of action was developed under the assumption that there was no statute of repose. The risk of overdeterrence of beneficial and legal conduct was addressed through alternative means, namely the requirement of proving additional elements which are not required for the express private causes of action. With this general distinction established, this Comment delineates two reasons why even though statutes of repose may be suitable for other securities regulations, they are not appropriate for private Rule 10b-5 actions. First, Rule 10b-5 requires scienter, while most express private causes of action do not. Second, violations which trigger the express private causes of action, especially those under section 9, are easier to detect than Rule $10 \mathrm{~b}-5$ violations.

318. Glus v. Brooklyn E. Dist. Terminal, 359 U.S. 231, 234 (1959) (noting that nothing in the language or history of the Federal Employers' Liability Act precludes the application of equitable estoppel); Holmberg v. Armbrecht, 327 U.S. 392, 397 (1946) (stating that equitable estoppel should be read into every statute of limitations); Cook v. Deltona Corp., 753 F.2d 1552, 1563 (11th Cir. 1985) (pointing out that equitable estoppel, though available in general, was inapplicable under the circumstances); Aldrich v. McCulloch Properties Inc., 627 F.2d 1036, 1042 (10th Cir. 1980) (noting that equitable tolling is read into statutes, absent contrary congressional intent).

319. Zenith Radio Corp. v. Hazeltine Research, 1nc., 401 U.S. 321, 338 (1971) (Sherman Act); New York v. Hendrickson Bros., 840 F.2d 1065, 1083 (2d Cir.) (Clayton Act), cert. denied, 488 U.S. 848 (1988); Borden, Inc. v. Spoor Behrins Campbell \& Young, Inc., 778 F. Supp. 695, 699 (S.D.N.Y. 1991) (RICO); Emrich v. Touche Ross \& Co., 846 F.2d 1190, 1199 (9th Cir. 1988) (RICO). The doctrine of equitable tolling is also read into the Reconstruction Era Civil Rights Act, the Commodity Exchange Act, the Federal Tort Claims Act, the National Labor Relations Act, the Railway Labor Act. the Death on the High Seas Act, the Omnibus Crime Control and Safe Streets Act of 1968, the Age Discrimination in Employment Act, the Emergency Petroleum Allocation Act, the Occupational Safety and Health Act of 1970, the Motor Vehicle Information and Cost Savings Act, the Employee Retirement Income Security Act, the Selective Service Act, the Copyright Act, the Tucker Act and others. Richard L. Marcus, Fraudulent Concealment in Federal Court: Toward a More Disparate Standard?, 71 GEo. L.J. 829, $831-33$ (1983). 1t is not uncommon for the courts to borrow principles and limitations from other federal causes of action. For example, the Supreme Court applied the four-year statute of limitations from the Clayton Act, 15 U.S.C. $\$ 15(b)$ (1988), to all civil suits brought under the Federal RICO Act. Agency Holding Corp. v. Malley-Duff \& Assocs., Inc., 483 U.S. 143, 156 (1987). Similarly, the common law for securities fraud has often followed the lead of antitrust adjudication. See, e.g., Bateman Eichler, Hill Richards, Inc. v. Berner, 472 U.S. 299, 305 (1985) (applying antitrust case law in restricting the availability of the doctrine of in pari delicto in securities fraud cases). 


\section{Scienter}

While statutes of repose may be necessary to prevent overdeterrence for some causes of action, Rule 10b-5 addresses the overdeterrence problem through other mechanisms. The most important distinction for our purposes is that the express private causes of action are strict liability statutes. $^{320}$ For example, section $16(\mathrm{~b})$ imposes strict liability on all insiders who earn "short-swing profits," contrast, Rule 10b-5 has a scienter requirement. Plaintiffs must prove that the defendants intended to commit fraud, or at least made reckless misrepresentations. Negligence cannot give rise to a Rule 10b-5 violation. ${ }^{322}$ One of the reasons the judiciary devised a scienter requirement is that, unlike the express private causes of action, Rule 10b-5 did not have a statute of repose. ${ }^{323}$ Regardless of what Congress might have intended in 1934, the case law developing the contours of Rule 10b-5 assumed that there was no statute of repose, and this played a large part in imposing strict requirements for scienter and reliance.

The scienter element is especially relevant given the legislative history of the three-year statute of repose for express private causes of action. When Congress debated whether the outer limit should be ten, six, or three years, the shortest limit was favored in part because "directors who might incur liability (particularly under sections 11 and 12(2) of the Securities Act) would be reluctant to serve in that capacity without a short period of repose." ${ }^{324}$ In short, Congress feared overdeterrence. If

320. See Currie v. Cayman Resources Corp., 835 F.2d 780, 782 (11th Cir. 1988) (intent to deceive not required in $\S 12(2)$ cases); $c f$. Kern County Land Co. v. Occidental Petroleum Corp., 411 U.S. 582, 595 (1973) (intent to profit on inside information not required in $\S 16(\mathrm{~b})$ cases). See generally Loss, supra note 135 , at 883-900.

Although the express private causes of action under the Securities and Exchange Act are often referred to as "strict liability" statutes, this is an oversimplification. For example, although liability under $\$ 11$ of the 1933 Act does not require intent to commit fraud, only the issuer is strictly liable in the traditional sense of strict liability. Other defendants are allowed to escape liability by proving that they engaged in "reasonable investigation" and believed that the statements at issue were true. Courts use a sliding scale to impose liability based on defendants' position, knowledge, expertise, relation to the issuer, and degree of actual participation in the registration process. See, e.g., Escott v. BarChris Constr. Corp., 283 F. Supp. 643, 684-97 (S.D.N.Y. 1968).

Additionally, while $\S 12(1)$ is a strict liability statute, $\S 12(2)$ allows defendants to escape liability by showing that they exercised "reasonable care." What constitutes "reasonable care" depends on the circumstances. See Sanders v. John Nuveen \& Co., 619 F.2d 1222, 1228 (7th Cir. 1980), cert. denied, 450 U.S. 1005 (1981); see also Davis v. Avco Fin. Servs., Inc., 739 F.2d 1057, 1068 (6th Cir. 1984) (discussing the criteria of "ordinary care"), cert. denied, 470 U.S. 1005, and cert. denied, 472 U.S. 1012 (1985). It is unclear whether reasonable care under $\S 12(2)$ is a less exacting standard than reasonable investigation under section 11. Sanders, 619 F.2d at 1228 . All of these standards are substantially less exacting than the scienter requirement of Rule 10b-5.

321. Reliance Elec. Co. v. Emerson Elec. Co., 404 U.S. 418, 422 (1972).

322. Ernst \& Ernst v. Hochfelder, 425 U.S. 185, 214 (1976).

323. Id. at 208-09 ("We also consider it significant that each of the express civil remedies in the 1933 Act allowing recovery for negligent conduct is subject to significant procedural restrictions not applicable under $\S 10(\mathrm{~b})$.") (citations and footnote omitted).

324. Bloomenthal, supra note 61, at 262 (citing 78 CONG. REC. 8199-200 (1934) (remarks of 
the laws against securities fraud were too broad, they might snare innocent people. ${ }^{325}$

The scienter requirement of Rule 10b-5 directly addresses these concerns. There is no such thing as a technical violation of Rule 10b-5. Undotted $i$ 's and uncrossed $t$ 's cannot give rise to liability under Rule $10 \mathrm{~b}-5$. While section 11 can be violated by a careless mistake, Rule 10b-5 cannot. Directors cannot incur liability without being, at least, reckless as to the actionable misrepresentation. ${ }^{326}$ Furthermore, for the purpose of Rule 10b-5, recklessness has been defined narrowly as "an extreme departure from the standards of ordinary care, ... which presents a danger of misleading buyers or sellers that is either known to the defendant or is so obvious that the actor must have been aware of it." ${ }^{327}$ Such a stringent standard prevents a commonplace mistake from creating liability. The standard of recklessness is sufficiently high that an innocent securities player will not be unfairly penalized.

To the extent that state of mind is relevant in the explicit causes of action, it is only relevant as part of an affirmative defense of good faith. The burden of proof rests on the defendant for such a defense. For example, section 18 of the 1934 Act, which punishes false or misleading reports filed with the SEC, shifts the burden of proof to the defendant, who must prove good faith in order to avoid liability. This shifting of the burden of proof was the primary reason Congress adopted short statutes of limitations without equitable tolling. ${ }^{328}$ Rule $10 \mathrm{~b}-5$ does not shift the burden of proof to the defendant. The plaintiff must prove all of the necessary elements by a preponderance of the evidence presented at trial.

\section{Ease of Detection}

The second major difference between violations of Rule 10b-5 and of the express private causes of action is that the former are far more diffcult to detect. This augments the significant risk of underdeterrence of Rule 10b-5 violations. Those causes of action with explicit statutes of repose are relatively easy to descry. For example, violations under sec-

Sen. Byrnes)). Even without a scienter requirement, the risk of exposure to liability is limited by the existence of directors' and officers' liability insurance, as well as by indemnification. See Alexander, supra note 289 , at $550-56$ (noting both the importance and limitations of such coverage).

325. A related fear was the risk of technical violations in a registration statement creating liability far in the future. 78 CoNG. REC. 8199 (1934) (remarks of Sen. Kean).

326. While the Supreme Court has not decided whether the Rule 10b-5 scienter requirement can be satisfied by merely reckless conduct, Herman \& MacLean v. Huddleston, 459 U.S. 375,378 n.4 (1983), some circuits have so held. See, e.g., McLean v. Alexander, 599 F.2d 1190, 1197 \& n.12 (3d Cir. 1979); Kevin R. Johnson, Liability for Reckless Misrepresentations and Omissions Under Section 10(b) of the Securities Exchange Act of 1934, 59 U. CIN. L. REV. 667, 677-95 (1991) (surveying the various standards of recklessness adopted by the circuit courts).

327. SEC v. Southwest Coal \& Energy Co., 624 F.2d 1312, 1321 n.17 (5th Cir. 1980) (quoting Franke v. Midwestern Okla. Dev. Auth., 428 F. Supp. 719, 725 (W.D. Okla. 1976)).

328. See 78 CoNG. REC. 8201 (1934) (remarks of Sen. Austin). 
tion 9 are not particularly difficult to discover. ${ }^{329}$ Section 9 of the 1933 Act addresses a static range of specific manipulative practices which occur on national securities exchanges and are easier for both the SEC and investors to monitor. Section 9 applies only to securities that are subject to the reporting requirements of the 1934 Act. This provides investors with a wealth of information, including annual and quarterly reports. Under section 16 of the 1934 Act, officers, directors and controlling shareholders must file reports with the SEC when they trade in the company's securities. Form 8-K must be filed with the SEC when certain material events occur. Audited financial statements must be filed and delivered to the sliareliolders in conjunction with these reports. Thus, the investigator looking for a section 9 violation has limited turf and plentiful resources.

In contrast, violations of Rule $10 \mathrm{~b}-5$ are substantially more difficult to detect and litigate. Section 10(b) applies to securities that are often unregistered and not subject to any reporting requirements. Investors are unlikely to receive any information, let alone information which would signal them that trouble may be brewing. This is not surprising given that section 10(b) was designed as a catch-all provision to punish abuses not covered under sections 9 and 10(a). Section 10(b) frauds often occur in unregistered securities, limited partnerslips, municipal bonds, venture capital schemes, and other transactions which are more difficult to oversee. Furtliermore, while the express private causes of action proscribe clearly defined conduct, Rule $10 \mathrm{~b}-5$ covers more vaguely defined behavior. Rule $10 \mathrm{~b}-5$ was meant to address new and cunning manipulative devices that Congress could not anticipate and proscribe by name. Consequently, potential victims of Rule 10b-5 inisconduct may not recognize the danger signs or know where to look for them. Because Rule $10 \mathrm{~b}-5$ covers a broader range of unregulated financial instruments and the illegal conduct is more dynamic, violations of Rule 10b-5 are more difficult to detect. For these reasons, a tliree-year statute of repose creates more risks of underdeterrence in the Rule $10 \mathrm{~b}-5$ context tlian it does for the express causes of action, which are better understood and more easily regulated.

In addition, to the extent that private suits often follow on the heels of SEC action, the Commission's ability to detect and litigate suspect conduct is vital for the private victims to bring suit. The SEC is more likely to discover violations of section 9.(e) than of Rule 10b-5. Relatively few stocks are traded on national exchanges, and it is easier for the SEC to monitor these than the tlousands of unregistered securities, joint ventures, and liinited partnerslips.

329. Analysis of $\S 9(\mathrm{e})$ is particularly relevant given that the Court chose to borrow the specific language from $\S 9(\mathrm{e})$ for Rule $10 \mathrm{~b}-5$ cases. 


\section{IV}

\section{Reimplementing Equitable Doctrines in Rule 10b-5 Cases}

A uniform statute of limitations for Rule 10b-5 cases is desirable. The pre-Lampf situation was unpalatable for many reasons. Indeed, the elimination of equitable tolling might arguably be a fair price to pay to achieve uniformity. However, uniformity and equity are by no means mutually exclusive. While there should be a uniform statute of limitations for Rule 10b-5 claims, the uniform limitations period can and should be subject to equitable tolling.

This Comment does not specifically address what the statute of limitations should be. However, a reasonable limitations period, which represents a twist on the one-year/three-year formulation, might be three years from the violation or one year from constructive discovery, whichever is later. This provides a three-year outer window and sense of repose for those businesspeople who have done nothing illegal and who lack scienter. The one-year bar after discovery provides a reasonable balance between extinguishing liabilities after constructive notice and providing plaintiffs with a reasonable length of time to engage in preliminary investigations and file suit after they have received storm warnings.

Aside from this limited speculation, this Section will not discuss actual numbers, but will instead discuss what factors should be required to toll a uniform federal statute of limitations for Rule 10b-5 cases. Before Lampf, various circuits interpreted and applied equitable tolling differently. Given the previous problems of nonuniformity, any reimplementation of the equitable tolling doctrine must be done consistently.

Before discussing the specifics of how equitable doctrines might work under a uniform federal statute of limitations for Rule 10b-5 cases, one observation bears repeating: revising the Lampf holding to permit equitable tolling would be neither dramatic nor revolutionary. Part III demonstrated why equitable tolling and equitable estoppel are necessary and desirable in Rule 10b-5 cases. Two questions remain. First, who should reimplement the doctrines? Second, what elements should a uniform federal equitable tolling doctrine embody for Rule 10b-5 cases?

The answer to the first question is fairly obvious. The most direct way to reimplement equitable doctrines is through congressional action. Congress can promulgate a specific statute of limitations for Rule 10b-5 that recognizes the distinctions between Rule 10b-5 and the express private causes of action contained in the Securities Acts. This is basically what Congress attempted to do in 1991 with S. 1533.330 Although this effort was defeated, the defeat was caused by political exigencies, not by any substantive problem with the concept of reimplementing equitable doctrines itself.

330. See supra notes $139-45$ and accompanying text. 
In lieu of legislative action, the judiciary could read equitable tolling and equitable estoppel back into Rule 10b-5 cases. Indeed, in his wellreasoned dissent in Lampf, Justice Kennedy argued just that. Judicial implementation of equitable doctrines is not a rejection of congressional judgment. This concern would be legitimate if this Comment argued for equitable tolling for section 13 or any of the other explicit limitations periods contained in the Exchange Act. However, Congress never enacted a private cause of action for Rule 10b-5. Consequently, it never considered the need to apply equitable doctrines. ${ }^{331}$ The courts have defined the contours of Rule 10b-5 from its infancy. Reimplementing equitable tolling and estoppel would simply undo a dictate that the Court itself imposed.

. The remainder of this Part will outline the proper elements of a uniform federal doctrine for equitable telling and equitable estoppel in Rule $10 \mathrm{~b}-5$ cases.

\section{A. Equitable Tolling}

Reimplementing equitable tolling warrants more analysis than simply asserting the need for tolling. Although all federal circuits applied equitable doctrines to Rule 10b-5 cases before Lampf, the ABA Task Force on Statute of Limitations for Implied Actions noted in 1988 that " $[t]$ he equitable tolling doctrine itself is applied differently by the various circuit courts of appeals." 332 Different courts identified different requirements for what constituted due diligence and what effect fraudulent concealment had on due diligence.

The analysis in Part III serves as a basis for defining the contours of a uniform federal tolling doctrine for Rule 10b-5 cases. The equitable tolling doctrine must be composed in harmony with the purposes of securities law and the rationales for statutes of limitations and repose. The Court has traditionally considered policy implications when formulating the contours of Rule 10b-5. ${ }^{333}$ The Court should consider the effects on enforcement and deterrence when developing the elements of equitable doctrines in Rule 10b-5 cases. This Section will discuss three factors which should be considered in developing a uniform federal equitable tolling doctrine: fraudulent concealment, due diligence, and fiduciary relationships.

331. In the absence of specific congressional intent, equitable tolling should be read into Rule $10 \mathrm{~b}-5$ as it is into every similar federal cause of action. But see Committee on Fed. Regulation of Sec., A.B.A., supra note 93, at 655 ("Against the clear evidence that Congress affirmatively intended that no tolling doctrine would be available for the express limitations periods for securities actions, it seems implausible that Congress intended such a doctrine to apply to the implied 10b-5 cause of action.").

332. Id. at 654.

333. See Blue Chip Stamps v. Manor Drug Stores, 421 U.S. 723, 737, 749 (1975). 


\section{Fraudulent Concealment}

Fraudulent concealment can be active or passive. Some courts have required active fraudulent concealment in order to toll statutes of limitations. $^{334}$ This Comment argues that, while a finding of fraudulent concealment should be a prerequisite to application of the equitable tolling doctrine, passive concealment may be sufficient in some cases. Before Lampf, courts agreed that active fraudulent concealment tolls the statute of limitations. However, courts were split on the significance of passive concealment. Treating active and passive concealment differently creates an arguably arbitrary distinction between ongoing fraud and self-concealing fraud.

Although allowing passive concealment to toll the statute of limitations creates some problems, disallowing it is even less palatable. First, in many cases passive concealment can be as malicious as active concealment; like the original fraud itself, it is planned and premeditated. Second, the harm to plaintiffs is the same in either case. If successful, both types of concealment prevent victims from realizing that they have a cause of action. Since they cause the same injury, it seems odd to punish one and not the other. Third, if only active concealment is punished, passive concealment may become a safe harbor in which wrongdoers will race to dock. Over a century ago, the Supreme Court recognized that both active and passive concealment are serious problems. ${ }^{335}$ If one is punished and the other not, it is not hard to surmise which will become more popular among securities fraud artists.

The argument for requiring active fraudulent concealment is that only those wrongdoers who engage in subsequent misconduct should lose the shield of the limitations period. Allowing passive concealment to toll the statute perpetuates the opportunity for liabilities that potential defendants thought had expired. While this concern is legitimate, it ignores the fact that some forms of securities fraud are inherently selfconcealing and wrongdoers know it. If there were an absolute requirement for active concealment, wrongdoers could sometimes structure their fraud so that it was self-concealing and thus avoid the reach of private Rule 10b-5 suits. ${ }^{336}$ For example, sellers of fraudulent bonds could simply wait three years and then default, free from Rule 10b-5 liability. This would vitiate deterrence and, indeed, encourage passive concealment until the three years had elapsed.

Permitting equitable tolling in cases of passive concealment would not necessarily impose never-ending liability on securities players.

334. See. e.g., Conmar Corp. v. Mitsui \& Co., 858 F.2d 499, 505 (9th Cir. 1988) ("Passive concealment of information is not enough to toll the [Clayton Act] statute of limitations ...."), cert. denied, 488 U.S. 1010 (1989).

335. See supra text accompanying note 25 .

336. See supra notes $189-226$ and accompanying text. 
Perhaps courts that rely on passive concealment to toll the statute could require plaintiffs to prove that the defendant possessed a heightened level of intent, such as intent to commit the initial fraud and to do it in a manner which would be undetectable for at least three years. The plaintiff's affirmative burden of proving intent to conceal the fraud should weed out frivolous accusations of securities fraud after the three years have elapsed. Adding an additional prong to the plaintiff's intent requirement should protect potential defendants against unfair lingering liabilities while blockading a safe harbor for wrongful conduct.

Another argument against allowing passive concealment to toll the statute is that the exception inay swallow the rule, because all Rule 10b-5 claims involve some level of concealment. Long ago the Pennsylvania Supreme Court held that passive concealment should not toll statutes of limitations because "[f]raud is always concealed. If it was not, no fraud would ever succeed." 337 However, the fact that fraud is part of the crine is not a justification for refusing to let passive concealment toll the statute of limitations. Otherwise, courts would be put in the anomalous situation of rewarding the successful criminal. Cominitting fraud would still be a crime; however, if the fraud is done properly (read: undiscoverable for three years), there is an absolute defense against private plaintiffs. The merits of the case need never be heard in court. Indeed, even the reputation of the wrongdoer, not to mention her pocketbook, may escape undamaged. Thus, the fear of rewarding cunning wrongdoers inust be balanced carefully against the need for screening out truly stale claims.

One solution might be to require plaintiffs to prove defendants' independent intent to passively conceal their fraud. For example, in the case of municipal bonds, intent can be shown by proving defendants' inaction regarding the project which the bonds were sold to finance. If a ten-year municipal bond were sold to finance a recreation facility, and the bond trustees paid the coupon interest for three years but never undertook any construction, this could be enough to show intent to passively conceal the fraud. Even though no further affirmative fraud was undertaken, the subsequent inaction inay show that the promoters never intended to build the facility. Proving intent to passively conceal may be difficult, but it is a reasonable burden for plaintiffs to bear in exchange for the opportunity to gain equitable tolling in the absence of affirmative concealment. The heightened intent requirement would protect defendants from boilerplate allegations of passive concealment.

Even without a heightened intent requirement, delayed litigation may be screened out. First, not all fraud is inherently self-concealing. Misstatements, such as those in Basic, and insider trading which immedi-

337. Smith v. Blachley, 47 A. 985,987 (Pa. 1901). Pennsylvania courts have since recognized that Blachley has been limited by Pennsylvania's recognition of a "discovery rule" for fraud. See Bickell v. Stein, 435 A.2d 610, 612 n.3 (Pa. Super. Ct. 1981). 
ately precedes major, easily observable events would start the one-year clock running. Second, even fraud which is self-concealing, such as issuing fraudulent long-term bonds, eventually reveals itself through storm warnings, if not outright exposure. Investors will still have only one year from the onset of these warning signs in which to bring suit. Thus, for those forms of fraud which are self-concealing, the limitations period will still eliminate many claims. Empirically, for the more than forty years that courts applied the equitable tolling doctrine to Rule 10b-5 cases, plaintiffs' suits were routinely dismissed on statute of limitations grounds.

In sum, both active and passive fraudulent concealment should be discouraged, not rewarded. An argument can be made that the proper policy response to discourage further concealment would be to create a separate cause of action for fraudulent concealment, instead of tolling. This would be inappropriate for several reasons. First, without equitable tolling the victims would not be compensated for the actual injury caused by the Rule 10b-5 violation. Second, creating a separate cause of action represents a far greater change than simply returning to the previous state of the law, which permitted equitable tolling. Third, any separate cause of action would be hard to define because "fraudulent concealment" depends on the circumstances, what the relationship was between the actors, and who knew what when. The factors and the relationships among them are fluid. Flexibility in taking these things into account makes sense when applying equitable doctrines, but more precision is needed to define an independent cause of action. Fourth, there can be fraudulent concealment only if there is something to conceal. The underlying fraud would still have to be proven. If the court must go through this fact-finding process anyway, there is no increased administrative efficiency in avoiding the Rule 10b-5 litigation and punishing the fraudulent concealment itself. If the complex relationships must be determined anyway, it makes sense to adjudicate the Rule 10b-5 claim in its entirety. Finally, there will be underdeterrence if the penalty for fraudulent concealment is less than the potential liability for the initial Rule $10 \mathrm{~b}-5$ violation. For example, if the crime of fraudulent concealment carries a fine of $\$ 10$ million, rational actors will be encouraged to fraudulently conceal all Rule 10b-5 violations when potential gains exceed $\$ 10$ million. If, on the other hand, the penalty were tied to the underlying securities fraud (either the amount of injury or ill-gotten gains), this underlying fraud should be litigated directly to compensate victims for their actual injury. Maintaining fraudulent concealment as a necessary element of equitable tolling is less dramatic and more manageable than alternative methods to discourage such concealment. 


\section{Due Diligence}

Before Lampf, there was no consensus on whether due diligence was always required to activate the equitable tolling doctrine. The courts that drew a distinction between active and passive fraudulent concealment imposed a due diligence requirement only in the absence of active concealment. For example, before they decided to follow the Third Circuit's Data Access analysis, the Second and Seventh Circuits "adopted the rule that where there is active concealment, a plaintiff's due diligence is irrelevant."338 The implied reasoning was that in cases of active concealment, a plaintiff's due diligence was unlikely to have any effect and therefore should not be required.

Due diligence should be required in all cases, regardless of whether there is active or passive concealment. Under a due diligence standard, inquiry notice is sufficient to start the limitations period running. Actual notice is not mandatory. Requiring due diligence as a prerequisite to invoking equitable tolling makes sense, since one of the rationales for reimplementing the doctrine is to encourage due diligence. This also compensates for allowing passive concealment to satisfy the fraudulent concealment requirement, thus striking a balance: passive concealment is sufficient if proven, but plaintiffs must exercise due diligence in all cases.

Although due diligence should always be required, the presence of active concealment is relevant and should affect a plaintiff's responsibilities. Before Lampf, some courts imposed different conditions on what type of notice-inquiry or actual - was required when there was active fraudulent concealment. For example, the Second Circuit eliminated constructive notice altogether, reasoning that "[u]nder the federal equitable tolling doctrine, the active concealment of fraudulent conduct tolls the statute of limitations in favor of the defrauded party until such time as he actually knew of the fraudulent conduct of the opposing party."339 However, if the standard were one of actual notice, this would not necessarily create the proper incentive for due diligence because potential plaintiffs could remain completely passive and bring suit several years after the violation, claiming no actual notice of the cause of action. In contrast, the inquiry notice standard places a burden on would-be plaintiffs to protect their own interests, without penalizing diligent plaintiffs, as the Lampf rule does, should the defendants' trickery elude the plaintiffs' diligence.

The proper effect of active concealment should be to lower the stan-

338. Borden, Inc. v. Spoor Behrins Campbell \& Young, Inc., 778 F. Supp. 695, 700 (S.D.N.Y. 1991) (citing Robertson v. Seidman \& Seidman, 609 F.2d 583, 593 (2d Cir. 1979); Sperry v. Barggren, 523 F.2d 708, 711 (7th Cir. 1975); Tomera v. Galt, 511 F.2d 504, 510 (7th Cir. 1975)).

339. Robertson v. Seidman \& Seidman, 609 F.2d 583, 593 (2d Cir. 1979) (citing Atlantic City Elec. Co. v. General Elec. Co., 312 F.2d 236, 239 (2d Cir. 1962), cert. denied, 373 U.S. 909 (1963)). 
dard for what constitutes due diligence; ${ }^{340}$ however, inquiry notice should still start the statute of limitations running. After all, if a potential victim has discovery notice, she has been alerted that soinething is aniss and she needs to take affirmative steps to preserve her rights and her investment. The standard for due diligence necessary to toll the statute of limitations and preserve the right to bring suit later must be sufficiently high that casual inquiries will not toll a limitations period. An inquiry that satisfies the due diligence requirement in a case where there is active concealınent may not suffice where there is only passive concealment. For exainple, if an investor were to ask for financial records and the wrongdoer manufactured and delivered fraudulent data, the plaintiff's due diligence requirement nay be satisfied. If, however, in the same situation the wrongdoer were to simply ignore the request, not wanting to engage in further affirmative concealment of the underlying fraud, the plaintiff's inere unanswered request should not satisfy the due diligence requirement. Indeed, such conduct should alert the investor to the fact that the Emperor is wearing shabby hand-me-downs and is quite possibly naked. Similarly, if the wrongdoer were to answer the investor's request with accurate data inplying the venture's failure, the mere request for information does not demonstrate due diligence and prompt tolling; rather, the data may represent the storm warning that starts the one-year clock running. Furthermore, because imputed discovery is sufficient to start the one-year clock, defendants can be protected against lingering liabilities by defining inquiry notice broadly enough that it is triggered at the first sign of a storm.

One might follow the lead of some states like California, which have defined "discovery" still more broadly in order to impose maximum responsibility on would-be plaintiffs. For the purpose of starting statutes of limitations under California law, discovery occurs either

(1) when the plaintiff had actual knowledge of facts sufficient to arouse suspicion in a reasonably prudent person, or (2) when the plaintiff had access to the "means of knowledge" of such facts and a reasonably prudent person would have used those means before making the relevant financial decision. Moreover, if a prudent person would have become suspicious from the knowledge obtained through the initial prudent inquiry and would have investigated further, a plaintiff will be deemed to have knowledge of facts which would have been disclosed in a more extensive investigation. ${ }^{341}$

Requiring such due diligence in all cases places a burden on the investor. But the alternative, represented by the current state of law

340. The contours of what constitutes "due diligence" will be affected by a number of factors, including storm warnings, fiduciary relationships, and the nature of concealment.

341. Briskin v. Ernst \& Ernst, 589 F.2d 1363, 1367 (9th Cir. 1978). 
which eliminates equitable tolling altogether, is even less satisfactory. In general, it is better to allow plaintiffs voluntarily to bear a burden that preserves their option to sue, than to have that option elininated entirely. The investor who chooses not to exercise due diligence is no worse off than under the current Lampf rule which refuses to reward due diligence in any case. Although a uniform standard which requires both fraudulent concealment and due diligence inay be more difficult to meet in soine jurisdictions than the variants on equitable tolling applied before Lampf, it still provides greater protection for victims of securities fraud than the current rule.

\section{Fiduciary Duty/Relationship}

If the defendant has a fiduciary duty to the plaintiff, she has a greater responsibility to be forthright. The plaintiff is more likely to trust the assurances and data of his fiduciary. Such reliance inheres in the relationship. Of course, a fiduciary relationship is not necessary to inaintain a cause of action under Rule 10b-5. Indeed, if the plaintiff uses the fraud-on-the-market theory to establish reliance, the plaintiff and defendant need never have inet nor even have heard of each other. ${ }^{342}$ However, the existence of fiduciary relationships affects both the fraudulent concealment and due diligence requirements of the equitable tolling doctrine.

First, soine courts require less evidence of fraudulent concealment when there is a fiduciary relationship between the plaintiff and defendant. $^{343}$ Second, fiduciary relationships reduce the standard for due diligence. Both results are reasonable and should be incorporated into a uniform equitable tolling principle for Rule 10b-5 cases. Because they occupy positions of trust, fiduciaries should be held to a higher standard of care. They know that their actions will receive less scrutiny. Thus, conduct that may be legal in an arms' length negotiation might constitute fraudulent concealment in a fiduciary relationship.

While exarnining the fiduciary relationships in a given transaction could permit dissimilar treatment of plaintiffs, at least the disparate treatment is a function of who they are and what they knew, not where they live, as under the pre-Lampf rule of borrowing from state law. Furtherinore, the securities laws were preinised on the understanding that soine investors need more protection than others. For exainple, accredited investors are treated differently for purposes of exeinptions froin registra-

342. The fraud-on-the-market theory is based on the notion that "an investor is entitled to rely on the integrity of the market (in the absence of evidence to rebut this presumption), even when they do not learn of the actual misrepresentation." JESSE H. CHOPER ET AL., CASES AND MATERIALS on CoRporations 416 (3d ed. 1989); see Basic Inc. v. Levinson, 485 U.S. 224, 250 (1988).

343. See Zola v. Gordon, 685 F. Supp. 354, 364 (S.D.N.Y. 1988). 
tion because they require less protection. ${ }^{344}$ Incorporating fiduciary concepts into a uniform federal equitable tolling doctrine is therefore consistent with the larger body of securities laws.

\section{B. Equitable Estoppel}

Fleshing out a uniform federal equitable estoppel rule for Rule 10b-5 cases is not as difficult a task as laying out rules for equitable tolling. There is no real split among the circuits over equitable estoppel doctrine. The philosophy is straightforward. If a would-be plaintiff suspects she has a Rule 10b-5 claim and the would-be defendant takes affirmative action to lull the victim into not bringing suit, that defendant can be estopped from arguing a statute of limitations defense. The important point for our purposes is that the defendant must do additional, affirmative acts after the initial fraud in order to trigger the doctrine. This subsequent activity makes it fair to hold a defendant accountable for misconduct which may have taken place years earlier. Like all equitable doctrines, the actual application of estoppel will depend on the specific circumstances of the case. Equitable estoppel is perhaps even more factdriven than other forms of equitable relief. Because the doctrine is so fact-dependent, little more need be said about it beyond arguing that federal judges should be given the discretion to apply equitable estoppel in Rule $10 \mathrm{~b}-5$ cases when fairness dictates.

\section{CONCLUSION}

Maintaining a statute of repose for Rule 10b-5 cases does not further any of the purposes behind the securities fraud laws. Instead of deterring securities fraud, the statute of repose facilitates it by discouraging due diligence and rewarding fraudulent concealment. The three-year statute of repose further decreases the probability of compensating victims and making wrongdoers disgorge ill-gotten gains. Conversely, none of the traditional rationales for statutes of repose apply in the context of Rule 10b-5 cases. The paper trail, which is often probative in securities cases, remains relatively clear over time, thus decreasing the usual risks of failed memories and stale claims. Uniform equitable doctrines can be formulated to protect honest businesspeople without providing a haven for wrongdoers. The Rule 10b-5 private cause of action was developed under the assumption that equitable tolling would apply. The risk of overdeterring beneficial behavior has already been addressed through other mechanisms. Scienter, materiality, and reliance were imposed in part because of the absence of a statute of repose. The Rule 10b-5 plaintiff already has to meet more requirements than plaintiffs using the

\footnotetext{
344. See 17 C.F.R. $\$ \S 230.501-.506$ (1992) (exempting certain sales of securities from registration).
} 
express private causes of action. The blind imposition of an additional hurdle ignores the purpose and evolution of the Rule $10 \mathrm{~b}-5$ private cause of action. To change the rules this late in the game serves only to deprive victims of their most effective weapon against securities fraud artists. Although the case for a uniform Rule 10b-5 limitations period is persuasive, uniformity should include application of equitable tolling and equitable estoppel in all Rule 10b-5 litigation. 
